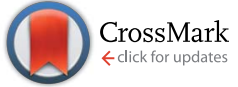

Cite this: J. Mater. Chem. A, 2016, 4, 16003

Received 22nd July 2016

Accepted 15th September 2016

DOI: $10.1039 / c 6 t a 06224 \mathrm{e}$

www.rsc.org/MaterialsA

\section{Niobium carbide nanofibers as a versatile precursor for high power supercapacitor and high energy battery electrodes $\uparrow$}

\author{
Aura Tolosa, ${ }^{\text {ab }}$ Benjamin Krüner, ${ }^{\text {ab }}$ Simon Fleischmann, ${ }^{\text {b }}$ Nicolas Jäckel, ${ }^{\text {ab }}$ \\ Marco Zeiger, ${ }^{\text {ab }}$ Mesut Aslan, ${ }^{a}$ Ingrid Grobelsek ${ }^{a}$ and Volker Presser*ab
}

\begin{abstract}
This study presents electrospun niobium carbide/carbon $(\mathrm{NbC} / \mathrm{C})$ hybrid nanofibers, with an average diameter of $69 \pm 30 \mathrm{~nm}$, as a facile precursor to derive either highly nanoporous niobium carbidederived carbon ( $\mathrm{NbC}-\mathrm{CDC}$ ) fibers for supercapacitor applications or niobium pentoxide/carbon $\left(\mathrm{Nb}_{2} \mathrm{O}_{5} / \mathrm{C}\right)$ hybrid fibers for battery-like energy storage. In all cases, the electrodes consist of binder-free and free-standing nanofiber mats that can be used without further conductive additives. Chlorine gas treatment conformally transforms $\mathrm{NbC}$ nanofiber mats into $\mathrm{NbC}-\mathrm{CDC}$ fibers with a specific surface area of $1508 \mathrm{~m}^{2} \mathrm{~g}^{-1}$. These nanofibers show a maximum specific energy of $19.5 \mathrm{~W} \mathrm{~h} \mathrm{~kg}^{-1}$ at low power and $7.6 \mathrm{~W} \mathrm{~h} \mathrm{~kg}^{-1}$ at a high specific power of $30 \mathrm{~kW} \mathrm{~kg}^{-1}$ in an organic electrolyte. $\mathrm{CO}_{2}$ treatment transforms $\mathrm{NbC}$ into $\mathrm{T}-\mathrm{Nb}_{2} \mathrm{O}_{5} / \mathrm{C}$ hybrid nanofiber mats that provide a maximum capacity of $156 \mathrm{~mA} \mathrm{~h} \mathrm{~g}^{-1}$. The presence of graphitic carbon in the hybrid nanofibers enabled high power handling, maintaining $50 \%$ of the initial energy storage capacity at a high rate of $10 \mathrm{~A} \mathrm{~g}^{-1}$ (64 C-rate). When benchmarked for an asymmetric full-cell, a maximum specific energy of $86 \mathrm{~W} \mathrm{~h} \mathrm{~kg}^{-1}$ was obtained. The high specific power for both systems, $\mathrm{NbC}-\mathrm{CDC}$ and $\mathrm{T}-\mathrm{Nb}_{2} \mathrm{O}_{5} / \mathrm{C}$, resulted from the excellent charge propagation in the continuous nanofiber network and the high graphitization of the carbon structure.
\end{abstract}

\section{Introduction}

Energy storage systems with high power and high energy ratings are in high demand for a variety of applications; ranging from mobile devices to power leveling for wind and solar energy installations. ${ }^{\mathbf{1}}$ In particular, electrochemical energy storage (EES) has emerged as a highly promising and efficient technology. ${ }^{2}$ With EES, energy can be stored by several mechanisms, ranging from physical ion electrosorption (electrical double-layer capacitors, EDLCs, also known as supercapacitors) and fast surface redox processes to ion intercalation (batteries)., ${ }^{3,4}$ The process of electrical double-

${ }^{a} I N M$ - Leibniz Institute for New Materials, 66123 Saarbrücken, Germany. E-mail: volker.presser@leibniz-inm.de

${ }^{b}$ Department of Materials Science and Engineering, Saarland University, 66123 Saarbrücken, Germany

$\uparrow$ Electronic supplementary information (ESI) available: Comprehensive Raman data (including peak deconvolution analysis), additional high resolution transmission and scanning electron micrographs, additional fiber diameter distribution analysis, additional gas sorption data, comprehensive data analysis (SEM, Raman, XRD, gas sorption analysis, and electrochemistry) for CDC materials obtained for $1 \mathrm{~h}$ of chlorine gas treatment (compared to $3 \mathrm{~h}$ in the manuscript), complementary thermogravimetric analysis and thermodynamic calculations with FACTSAGE, and additional electrochemical galvanostatic benchmarking of a half-cell and full-cell setup for the battery-system. See DOI: 10.1039/c6ta06224e layer formation is a non-faradaic interface mechanism, enabling high specific power and long cycling lifetime, but rather low specific energy. ${ }^{5}$ Ion intercalation batteries accomplish charge storage and recovery by faradaic charge transfer between the electrolyte ions and the electrode materials. ${ }^{6}$ By this way, high specific energy can be obtained, while the cycling lifetime and power handling are limited by mechanical/structural degradation and diffusion processes through bulk materials. ${ }^{6}$ The ultimate goal is to achieve a combination of high power and high energy ratings. This is sought to be achieved by the development of hybrid technologies, such as lithium ion capacitors, ${ }^{7}$ and employment of rapid pseudocapacitive materials ${ }^{8}$ or redox-active electrolytes., ${ }^{\mathbf{9}, 10}$

A particularly attractive group of electrode materials are binder-free and free standing fiber mats. ${ }^{11,12}$ The open-mesh percolated network and the possibility of creating a continuous active material are highly attractive to achieve an improved power performance. Commonly, different precursor materials and electrode architectures are employed when exploring supercapacitor or battery-like systems. The challenge is to satisfy the very different requirements for these two applications: (1) nanoporous carbon with a highly tailorable and controllable pore size distribution and (2) a redox-active material enabling, for example, rapid and reversible Li-ion intercalation.

Nanoporous carbon fibers have been extensively explored for supercapacitor applications, especially those derived from high 
carbon yield polymers such as polyacrylonitrile (PAN) and polymer blends such as polyvinylpyrrolidone and methylacrylate as pore formers. ${ }^{13}$ To achieve a large surface area, physical or chemical activation of such PAN fibers can be employed. ${ }^{13,14}$ An alternative approach, which allows more control over the size and size distribution of nanopores, is the selective removal of metal atoms from metal carbide fibers. ${ }^{15}$ This can be done via thermal treatment with chlorine gas, yielding highly nanoporous carbon (carbide-derived carbon, CDC). ${ }^{16}$ So far, this approach has only been employed with electrospun fibers of TiC-CDC ${ }^{12,17}$ and SiC-CDC. ${ }^{18,19}$ More detailed work has been carried out on the synthesis of CDC powders, including systems such as $\mathrm{NbC}^{20} \mathrm{TiC}^{21,22}$ or $\mathrm{B}_{4} \mathrm{C},,^{23}$ with surface areas between 1000 and $3000 \mathrm{~m}^{2} \mathrm{~g}^{-1}$ and pore volumes between 0.5 and $2 \mathrm{~cm}^{3} \mathrm{~g}^{-1}$.

Carbon hybrid fibers containing redox-active materials have been proposed for pseudocapacitors, redox-hybrids, and battery-like energy storage. ${ }^{24,25}$ Different approaches have been reported, including functionalization of carbon fibers with quinones, ${ }^{26}$ coating with pseudocapacitive oxides (mainly $\left.\mathrm{MnO}_{2}\right),{ }^{27,28}$ and synthesis of composite fibers with $\mathrm{RuO}_{2}$ or NiO..$^{29,30}$ The hybridization of carbon and redox-active materials combines two synergetic aspects: the high electrical conductivity of carbon with the high faradaic charge storage capacity of redox-active materials. The latter often lack a good electron propagation ability, which makes the presence of a conductive phase mandatory in order to achieve a high power performance. A very promising metal oxide that has not been explored so far for carbon-hybrid fibers is niobium pentoxide $\left(\mathrm{Nb}_{2} \mathrm{O}_{5}\right)$. Niobium pentoxide presents a high specific energy and power capability related to fast lithium ion intercalation within (110) or (001) planes, depending on the crystal phase. ${ }^{\mathbf{8}, 31,32}$ There are several $\mathrm{Nb}_{2} \mathrm{O}_{5}$ crystal phases based on octahedrally coordinated niobium atoms and the most common phases are TT- $\mathrm{Nb}_{2} \mathrm{O}_{5}$ (pseudohexagonal), $\mathrm{T}-\mathrm{Nb}_{2} \mathrm{O}_{5}$ (orthorhombic), $\mathrm{M}-\mathrm{Nb}_{2} \mathrm{O}_{5}$ (tetragonal), and $\mathrm{H}-\mathrm{Nb}_{2} \mathrm{O}_{5}$ (monoclinic). ${ }^{33}$ The monoclinic phase is the most thermodynamically stable (formed above $1000^{\circ} \mathrm{C}$ ), while the TT-phase is the least thermodynamically stable and is formed at lower temperatures $\left(400-500{ }^{\circ} \mathrm{C}\right) .^{33}$

First studies showed that $\mathrm{Nb}_{2} \mathrm{O}_{5}$ presents Li-ion intercalation at a potential below $2.0 \mathrm{~V} v$ s. $\mathrm{Li} / \mathrm{Li}^{+}{ }^{34}$ and it was initially explored as a cathode material in secondary lithium batteries using a Li-metal anode. ${ }^{35}$ Different polymorphs have later been investigated as electrode materials not just for Li-ion batteries, ${ }^{36}$ but also for carbon $/ \mathrm{Nb}_{2} \mathrm{O}_{5}$ hybrid systems. ${ }^{\mathbf{8}, 37}$ It has been observed that the energy storage capacity of $\mathrm{Nb}_{2} \mathrm{O}_{5}$ for lithiumion batteries highly depends on its crystalline structure; $\mathrm{H}-\mathrm{Nb}_{2} \mathrm{O}_{5}$ shows the highest specific energy, delivering a second cycle discharge capacity of $242 \mathrm{~mA} \mathrm{~h} \mathrm{~g}^{-1}$, compared to $152 \mathrm{~mA} \mathrm{~h} \mathrm{~g}^{-1}$ for TT- $\mathrm{Nb}_{2} \mathrm{O}_{5} \cdot{ }^{35,36}$ For battery-like systems, TT-, T- and $\mathrm{M}-\mathrm{Nb}_{2} \mathrm{O}_{5}$ have been widely studied. $\mathrm{T}-\mathrm{Nb}_{2} \mathrm{O}_{5}$ has shown superior power handling due to fast two dimensional $\mathrm{Li}^{+}$transport within the crystal structure that causes no phase transition during the electrochemical reaction. ${ }^{\mathbf{8}, 37}$ So far, polymer-bound electrodes have been mainly produced by mixing $\mathrm{Nb}_{2} \mathrm{O}_{5}$ fibers, ${ }^{36}$ nanosheets, ${ }^{38}$ and nanoparticles ${ }^{8,31}$ with conductive additives. Thin electrodes without conductive additives have also been explored by direct drop casting of $\mathrm{Nb}_{2} \mathrm{O}_{5}$ nanoparticles on the current collector $^{32}$ or from thin mesoporous films. ${ }^{39}$ However, this approach remains limited with regards to scalability.

Our work presents, for the first time, electrospun $\mathrm{NbC} / \mathrm{C}$ hybrid nanofibers as a versatile precursor to derive either (1) NbC-CDC nanofibers for high power, capacitive energy storage or (2) $\mathrm{Nb}_{2} \mathrm{O}_{5} / \mathrm{C}$ hybrid nanofibers for high energy, battery-like energy storage. We will first establish the synthesis process and optimum processing parameters, and then provide comprehensive material characterization. Supercapacitor performance was benchmarked in an organic electrolyte $\left(1 \mathrm{M}\right.$ TEA-BF ${ }_{4}$ in acetonitrile), and the battery-like system is investigated in $1 \mathrm{M}$ $\mathrm{LiClO}_{4}$ in ethylene carbonate/dimethyl carbonate electrolyte. The choice of different electrolytes was motivated by enabling high ion mobility for the supercapacitor system, while a large voltage stability window and lithium intercalation were needed for the battery-like system. A key feature of our system is the ability to directly use free-standing, binder-free nanofiber mats; hence, the need for a binder (i.e., dead mass) is eliminated, the possible blocking of pores by the polymer binder is avoided, and an improved electrical conductivity of the electrode can be obtained, as shown in our recent study. ${ }^{18}$

\section{Experimental description}

\section{Materials synthesis}

Niobium carbide/carbon hybrid nanofibers were synthesized following a sol-gel synthesis, as described in our previous work. ${ }^{40}$ Niobium $n$-butoxide (NbBO) (99\% metal basis) was purchased from Alfa Aesar, while acetic anhydride $\left(\mathrm{Ac}_{2} \mathrm{O}\right)(\geq 99 \%$ purity), anhydrous $N, N$-dimethylformamide (DMF) $\quad(99.8 \%$ purity), and polyvinylpyrrolidone (PVP) $\left(M_{\mathrm{w}} \approx 1300000\right.$ $\mathrm{g} \mathrm{mol}^{-1}$ ) were purchased from Sigma Aldrich. The spinning dope was prepared by mixing 9 mass $\% \mathrm{NbBO}$ and 2 mass $\% \mathrm{Ac}_{2} \mathrm{O}$ for 2 min. Then, 79 mass\% of DMF (solvent) and 10 mass\% of PVP (carrier polymer) were added. The spinning dope was stirred for $48 \mathrm{~h}$ prior to electrospinning, until a translucent solution was obtained. The fiber mats were produced by electrospinning in a MECC nanofiber system. The solution was pumped at $0.5 \mathrm{~mL} \mathrm{~h}^{-1}$ through a spinneret (inner diameter: $400 \mu \mathrm{m}$ ), inductively charged at $23 \mathrm{kV}$. The fibers were collected at a distance of $165 \mathrm{~mm}$ from the spinneret. The humidity and the temperature were maintained between 10 and $20 \%$ and 25 and $30{ }^{\circ} \mathrm{C}$.

Post spinning, the as-spun fibers were exposed at room humidity for $72 \mathrm{~h}$, to promote further hydrolysis and condensation reactions. Annealing was performed under 99.5\% argon in a graphite heated furnace, Thermal Technology. The fibers were heated at $5{ }^{\circ} \mathrm{C} \mathrm{min}{ }^{-1}$ to $400{ }^{\circ} \mathrm{C}$ for $3 \mathrm{~h}$, and then heated to 1500 or $1700{ }^{\circ} \mathrm{C}$ for $4 \mathrm{~h}$ for carbothermal reduction.

Synthesis of niobium carbide-derived carbon nanofibers. The NbC/C fibers pyrolyzed at $1500{ }^{\circ} \mathrm{C}(\mathrm{NbC}-1500)$ were used for carbide-to-carbon conversion. Chlorine gas treatment was carried out in a quartz tube furnace (Gero HTRH) which was constantly purged with $\mathrm{Ar}\left(50 \mathrm{~cm}^{3} \mathrm{~min}^{-1}\right)$. NbC-1500 fibers were heated at $15{ }^{\circ} \mathrm{C} \mathrm{min}^{-1}$, until reaching the temperature of the treatment $\left(400,600\right.$, or $\left.900^{\circ} \mathrm{C}\right)$, and treated with $\mathrm{Cl}_{2}$ for 1 or $3 \mathrm{~h}$ (flow rate: $10 \mathrm{~cm}^{3} \mathrm{~min}^{-1}$ ). A post annealing process with 
hydrogen gas $\left(10 \mathrm{~cm}^{3} \mathrm{~min}^{-1}\right)$ was applied at $600{ }^{\circ} \mathrm{C}$ for $3 \mathrm{~h}$ to remove residual chlorine species present in the sample. Then, the samples were cooled to room temperature.

Synthesis of niobium pentoxide-carbon hybrid nanofibers. The NbC/C fibers pyrolyzed at $1700{ }^{\circ} \mathrm{C}(\mathrm{NbC}-1700)$ were used for carbide-to-oxide conversion. Two different oxidative atmospheres were studied, $\mathrm{CO}_{2}$ and air. $\mathrm{NbC}-1700$ fibers were thermally annealed between 450 and $500{ }^{\circ} \mathrm{C}$ in a VG Scienta GP-CVD tube furnace under synthetic air (flow rate: $50 \mathrm{~cm}^{3} \mathrm{~min}^{-1}$ ) at $5{ }^{\circ} \mathrm{C} \mathrm{min}^{-1}$ for $3 \mathrm{~h}$. Thermal annealing under $\mathrm{CO}_{2}\left(50 \mathrm{~cm}^{3} \mathrm{~min}^{-1}\right)$ was done at $850{ }^{\circ} \mathrm{C}$ in a Xerion XROTATE tube furnace at $5^{\circ} \mathrm{C} \min ^{-1}$ for $1 \mathrm{~h}$.

\section{Materials characterization}

Structural and chemical characterization. The morphology of the fibers was examined with a JEOL JSM 7500F field emission scanning electron microscope (SEM). All samples were fixed on steel sample holders with sticky carbon tape. The $\mathrm{Nb}_{2} \mathrm{O}_{5}$ containing fibers were coated prior to the imaging with a thin layer of platinum in a JEOL Autofine Coater. ImageJ software was used to process the SEM micrographs and diameters of at least 100 individual fibers were measured. For high resolution analysis of the fibers, a JEOL JEM-2100F high resolution transmission electron microscope (TEM) was employed at $200 \mathrm{kV}$. In the TEM, selected area electron diffraction (SAED) was carried out for the $\mathrm{Nb}_{2} \mathrm{O}_{5}$ containing fibers. TEM samples were prepared by sonicating the fibers in ethanol for $3 \mathrm{~min}$, and drop casting them on a carbon film on a copper grid.

The composition of the fibers was determined by energy dispersive X-ray spectroscopy (EDX) using an X-Max-150 detector from Oxford Instruments attached to the SEM chamber. The spectra of 10 fibers were measured using an accelerating voltage of $10 \mathrm{kV}$, in uncoated fibers attached to a sticky carbon tape. A silicon standard was used for standardization.

XRD diffractograms were recorded with a Bruker D8 Discover diffractometer using $\mathrm{Cu}_{\mathrm{K} \alpha}$ radiation $(0.154 \mathrm{~nm}$; without a monochromator) with a step size of $0.02^{\circ}$ and a measurement time of 1-3 s per step. The system was calibrated with a corundum alumina standard. The samples were pestled and placed on a sapphire single crystal for the measurement. The full width at half maximum (FWHM) was measured by using EVA software from Bruker. The values of the average coherence length (roughly corresponding with the domain size) were obtained using the Scherrer equation. ${ }^{41}$

Raman spectra were recorded with an InVia Raman system, from Renishaw, using a laser with $532 \mathrm{~nm}$ excitation wavelength and $0.5 \mathrm{~mW}$ power on the sample with a spectral resolution of ca. $1.2 \mathrm{~cm}^{-1}$, using a $50 \times$ objective (numeric aperture: 0.9 ). Peak analysis was performed by baseline correction and assuming four Voigt peak fittings between 500 and $2000 \mathrm{~cm}^{-1}$. In situ Raman spectra were recorded during thermal treatment under synthetic air (heating rate $5{ }^{\circ} \mathrm{C} \mathrm{min}^{-1}$ ) by using a temperature controlled Linkam T95-HT heating stage. A laser with $532 \mathrm{~nm}$ excitation wavelength was used, which exposed the sample to a power of $0.5 \mathrm{~mW}$ at the focal point.

Thermogravimetric analysis (TGA) was carried out in synthetic air or $\mathrm{CO}_{2}$ with a heating rate of $5{ }^{\circ} \mathrm{C} \min ^{-1}$ with a TG $209 \mathrm{~F} 1$
Libra system (Netzsch). Nitrogen gas sorption measurements were carried out at $-196{ }^{\circ} \mathrm{C}$ with an Autosorb iQ system (Quantachrome), after outgassing at $300{ }^{\circ} \mathrm{C}$ for $10 \mathrm{~h}$ under vacuum conditions (about $10^{2} \mathrm{~Pa}$ ) to remove volatile surface functionalities present in the sample. The specific surface area (SSA) was calculated with the Quantachrome ASiQwin software using the Brunauer-Emmett-Teller (BET) equation ${ }^{42}$ in the linear relative pressure range of $0.05-0.2$. Using the quenched-solid density functional theory (QSDFT), ${ }^{43}$ the SSA and pore size distribution (PSD) were calculated assuming slit-shaped pores and pore sizes between 0.56 and $37.5 \mathrm{~nm}$. The values of the total pore volume correspond to $p / p_{0}=0.95$. The values of the mean pore size are volume-weighted. Thermodynamic calculations were carried out with FactSage 7.0 (GTT-technologies).

Electrochemical measurements. Electrochemical measurements were carried out with a potentiostat/galvanostat (VSP300 from Bio-Logic), using cyclic voltammetry (CV) and galvanostatic cycling with potential limitation (GCPL). The electrodes were tested in custom-built polyether ether ketone (PEEK) cells with spring loaded titanium pistons as a three electrode system. $8 \mathrm{~mm}$ diameter working electrode discs (1-2 mg, $80 \mu \mathrm{m}$ thickness) were punched out of the free-standing fiber mats. Activated carbon (type YP-50F, Kuraray Chemicals) with 5 mass\% polytetrafluoroethylene (PTFE) films was used as a quasi-reference electrode. ${ }^{44}$ Working and counter electrodes were separated by a $13 \mathrm{~mm}$ diameter glass-fiber separator (GF/D from Whatman) and placed between $12 \mathrm{~mm}$ diameter carbon-coated aluminum current collectors (Zflo 2653, Exopack technologies). After assembling, the cells were dried at $2 \mathrm{kPa}, 120{ }^{\circ} \mathrm{C}$ for $12 \mathrm{~h}$. After cooling down, the cells were placed in an argon glove box (MBraun Labmaster 130, $\mathrm{O}_{2}$ and $\mathrm{H}_{2} \mathrm{O}<1 \mathrm{ppm}$ ), and filled with the corresponding electrolyte.

For electrochemical characterization of electrical double-layer capacitor cells, the performance of NbC-CDC electrodes was characterized in half- and symmetric full-cell setups employing $1 \mathrm{M}$ tetraethylammonium tetrafluoroborate $\left(\mathrm{TEA}-\mathrm{BF}_{4}\right)$ in electrochemical grade acetonitrile (ACN) from BASF as the electrolyte. Half-cell tests were performed with an oversized activated carbon (AC) counter electrode $(10 \mathrm{~mm}$ diameter, $15 \mathrm{mg}$ mass; YP-80F from Kuraray Chemicals with 5 mass\% PTFE). Symmetric full-cell tests used two NbC-CDC fiber electrodes of the same mass. CVs were recorded at $10 \mathrm{mV} \mathrm{s}^{-1}$ scan rate in the potential range from $-1.0 \mathrm{~V}$ to $+1.0 \mathrm{~V}$ $v s$. carbon in half-cells and from 0 to $+2.7 \mathrm{~V}$ cell voltage for fullcells. Galvanostatic cycling for half-cells was carried out from $-1.0 \mathrm{~V}$ to $+1.0 \mathrm{~V} v s$. carbon at $2 \mathrm{~A} \mathrm{~g}^{-1}$ with a holding time of $10 \mathrm{~min}$. The specific capacitance $\left(C_{\mathrm{sp}}\right)$ was calculated by integrating the discharge current between $t_{0}$, the discharge starting time, and $t$, the end time of discharge, divided by $U$ (voltage $v s$. carbon or applied cell voltage, for half- and full-cells, respectively) via eqn (1). ${ }^{45} m$ corresponds to the mass of the CDC electrode for the half-cells, and for the full-cells it corresponds to the mass of both electrodes divided by four.

$$
C_{\mathrm{sp}}=\frac{1}{m} \frac{\left(\int_{t_{0}}^{t} I \mathrm{~d} t\right)}{U}
$$


Rate handling was quantified with the $I R$ drop corrected voltage measured after $5 \mathrm{~s}$ resting time. Electrical impedance spectroscopy (EIS) was performed in the range of $100 \mathrm{kHz}$ to $100 \mathrm{mHz}$ at $0 \mathrm{~V}$ with 10 points per decade and averaged over 5 measurements. Performance stability tests were carried out in full-cells by galvanostatic cycling over 10000 cycles to $2.5 \mathrm{~V}$ at $1 \mathrm{~A} \mathrm{~g}^{-1}$.

For electrochemical characterization of battery-like cells, $\mathrm{Nb}_{2} \mathrm{O}_{5} / \mathrm{C}$ electrodes were characterized by using half- and asymmetric full-cell setups in $1 \mathrm{M}$ lithium perchlorate $\left(\mathrm{LiClO}_{4}\right)$ in electrochemical grade ethylene carbonate (EC)/dimethyl carbonate (DMC) from Sigma-Aldrich (volume ratio $1: 1$ ). Half-cell tests were performed with an oversized AC counter electrode (10 mm diameter, $15 \mathrm{mg}$ mass; YP-80F from Kuraray Chemicals with 5 mass\% PTFE) and asymmetric full-cell tests by combining a $\mathrm{Nb}_{2} \mathrm{O}_{5} / \mathrm{C}$ hybrid electrode with an AC electrode (YP-80F with 5 mass\% PTFE). Charge balancing for asymmetric full-cells was achieved by mass balancing, according to the capacity values obtained by half-cell measurements at $0.1 \mathrm{Ag}^{-1}$. The lower gravimetric capacity of the AC electrode compared to the $\mathrm{Nb}_{2} \mathrm{O}_{5} / \mathrm{C}$ electrode was compensated by using electrodes with different masses. The mass of the AC electrode was between 1.5 and 2.5 times higher than the mass of the $\mathrm{Nb}_{2} \mathrm{O}_{5} / \mathrm{C}$ electrode. The cell voltage was chosen in order to achieve a maximum potential of $-2.0 \mathrm{~V} v s$. carbon at the negative electrode $\left(\mathrm{Nb}_{2} \mathrm{O}_{5} / \mathrm{C}\right)$. For $\mathrm{Nb}_{2} \mathrm{O}_{5} / \mathrm{C}$ fiber electrodes, CVs were recorded at $1 \mathrm{mV} \mathrm{s}^{-1}$ scan rate in the potential range from 0 to $-2.0 \mathrm{~V} v s$. carbon in half-cells and from 0 to $+3.6 \mathrm{~V}$ cell voltage in full-cells. Rate handling for half- and asymmetric full-cells was carried out by GCPL, using the same potential ranges, from 0.1 to $40 \mathrm{~A} \mathrm{~g}^{-1}$ with a holding time of $10 \mathrm{~min}$. Capacity $\left(Q_{\mathrm{sp}}\right)$ was calculated by integrating the discharge current between $t_{0}$, the discharge starting time, and $t$, the end time of discharge, and normalized to the electrode mass, $m$, via eqn (2):

$$
Q_{\mathrm{sp}}=\frac{1}{m}\left(\int_{t_{0}}^{t} I \mathrm{~d} t\right)
$$

Performance stability tests were carried out by galvanostatic cycling over 5000 cycles from 0 to $-2.0 \mathrm{~V} v s$. carbon and $3.0 \mathrm{~V}$ cell voltage at $1 \mathrm{~A} \mathrm{~g}^{-1}$ for half- and asymmetric full-cells, respectively.

Data from the electrodes with the best electrochemical performance for electrical double-layer capacitors or batterylike systems are presented in a Ragone plot. Using GCPL data of full-cells (asymmetric and symmetric), specific energy $\left(E_{\mathrm{sp}}\right)$ and specific power $\left(P_{\mathrm{sp}}\right)$ were calculated, using eqn (3) and (4), respectively, with $U$ and $I$ as the voltage and current applied to the full-cell, and $M$ corresponds to the mass of both electrodes (positive and negative electrodes).

$$
\begin{gathered}
E_{\mathrm{sp}}=\frac{\left(\int_{t_{0}}^{t} U \mathrm{~d} t \cdot I\right)}{M} \\
P_{\mathrm{sp}}=\frac{E_{\mathrm{sp}}}{t-t_{0}}
\end{gathered}
$$

\section{Results and discussion}

\section{Niobium carbide/carbon hybrid nanofibers}

We briefly outline the important aspects of $\mathrm{NbC} / \mathrm{C}$ hybrid nanofiber synthesis, which can be found in more detail in our previous work. ${ }^{40}$ Using $\mathrm{NbBO}$ as the sol-gel precursor and PVP as the carrier polymer, we have established a facile synthesis route for hybrid nanofibers with an average fiber diameter of $69 \pm 30 \mathrm{~nm}$. This approach employs electrospinning to obtain free-standing fiber mats, and thermal treatment yielding $\mathrm{NbC} / \mathrm{C}$ hybrid nanofibers via carbothermal reduction. The fibers synthesized at $1700{ }^{\circ} \mathrm{C}(\mathrm{NbC}-1700)$ presented a higher crystallinity when compared to the fibers synthesized at $1500{ }^{\circ} \mathrm{C}$ (NbC-1500), with an NbC average domain size (i.e., XRD coherence length) of $65 \mathrm{~nm}$ compared to $38 \mathrm{~nm}$, respectively. ${ }^{40}$ Also, at a higher pyrolysis temperature, carbon presented a higher degree of graphitization (see ESI, Fig. S1†). NbC/C fibers were later evaluated as a versatile precursor to derive (1) NbC-CDC nanofibers and (2) $\mathrm{Nb}_{2} \mathrm{O}_{5} / \mathrm{C}$ hybrid nanofibers. To promote the carbide-to-carbon conversion, a lower degree of carbon ordering is preferred. ${ }^{22}$ The graphitic carbon engulfing the metal carbide crystals affects the reaction kinetics between $\mathrm{Cl}_{2}$ and the $\mathrm{NbC}$; therefore, longer $\mathrm{Cl}_{2}$ treatment durations or higher synthesis temperatures will be needed for complete etching. To promote the carbide-to-oxide conversion without a complete loss of carbon, a higher degree of carbon ordering is desirable due to the higher stability in oxidizing atmospheres. ${ }^{22}$ Therefore, NbC-1500 was chosen as the precursor for NbC-CDC, and NbC-1700 was preferable as the precursor for $\mathrm{Nb}_{2} \mathrm{O}_{5} / \mathrm{C}$ hybrid nanofibers.

\section{Niobium carbide-derived carbon nanofibers}

Material characterization. NbC-1500 fibers were treated with chlorine gas at different temperatures and holding times. After $\mathrm{Cl}_{2}$ treatment, a mass loss between 72 and 79 mass\% was obtained, leaving behind mainly carbon. According to the EDX results (see ESI, Table S1 $\dagger$ ), the starting precursor (NbC-1500) contained about 74 mass\% of niobium, which, after $\mathrm{Cl}_{2}$ treatment, was almost completely removed $(<1$ mass\%). The remaining niobium may be present as $\mathrm{NbCl}_{5}$ trapped in the carbon structure or as very small residual NbC domains (ca. $2 \mathrm{~nm}$ ), as shown by TEM micrographs at a few positions throughout the samples (see ESI, Fig. S2A $\dagger$ ).

No influence on the morphology is observed as a function of the heat treatment parameters. The SEM micrographs of fibers treated for $3 \mathrm{~h}$ (Fig. 1) and $1 \mathrm{~h}$ (see ESI, Fig. S3†) show a mean fiber diameter of around $61 \pm 22 \mathrm{~nm}$ (see ESI, Fig. S2B $\dagger$ ). The conformal etching process during the CDC transformation is not expected to modify the macroscopic structure of the material, but rather the nanoporosity of the material (Fig. 1, inset). ${ }^{\mathbf{1 6}}$ The TEM micrograph of the sample after $3 \mathrm{~h}$ holding time at $400{ }^{\circ} \mathrm{C}$ shows mesopores, which at higher temperatures become more organized, leading to a more densified fiber structure.

A better understanding of the influence of the treatment conditions on the carbon structure is achieved by the analysis of the Raman spectra and XRD patterns (Fig. 2). The data of samples treated for $1 \mathrm{~h}$ are presented in the ESI (see Fig. S4†). 

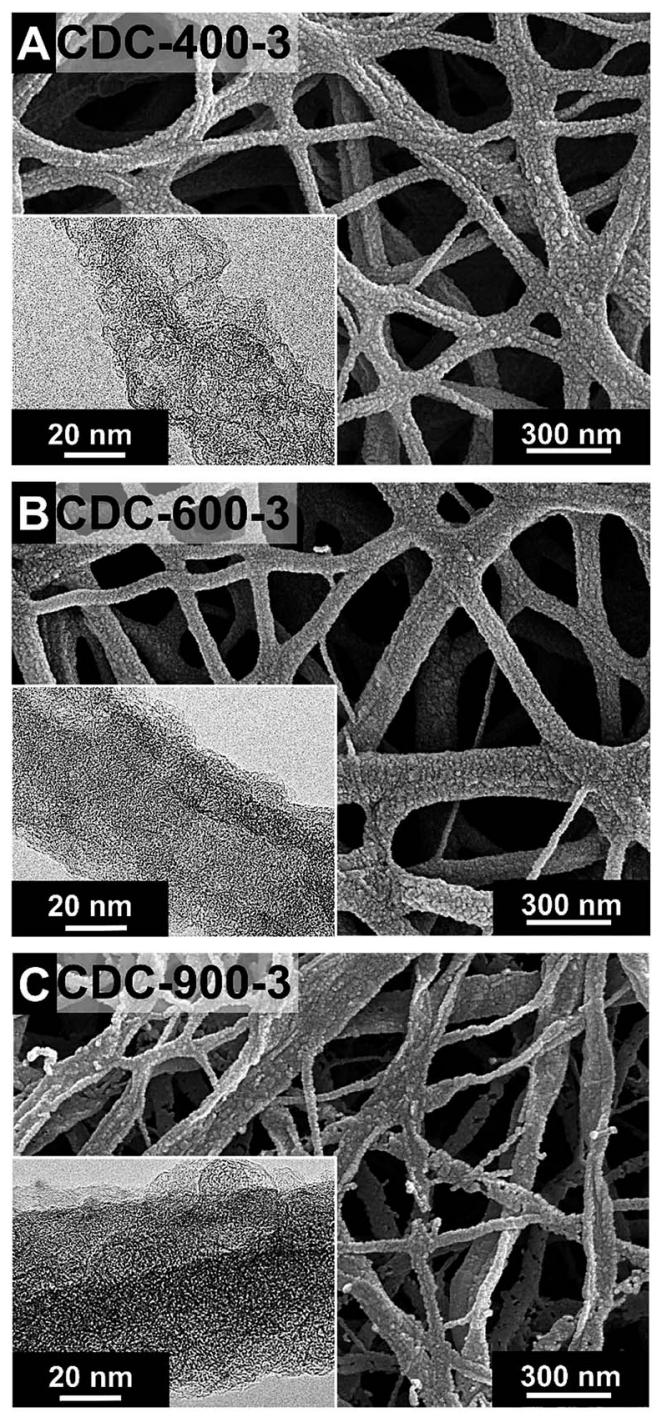

Fig. 1 SEM and TEM micrographs (inset) of $\mathrm{NbC}-\mathrm{CDC}$ fibers synthesized by chlorine gas treatment for $3 \mathrm{~h}$ at (A) $400^{\circ} \mathrm{C}$, (B) $600^{\circ} \mathrm{C}$, and (C) $900^{\circ} \mathrm{C}$.

To understand these data, we have to consider the presence of two different carbon species: (1) carbon formed during pyrolysis at $1500{ }^{\circ} \mathrm{C}$ and present in $\mathrm{NbC} / \mathrm{C}$ hybrid nanofibers and (2) carbide-derived carbon formed between 400 and $900{ }^{\circ} \mathrm{C}$ via chlorine gas treatment of NbC nanocrystals. The latter co-exists in NbC-CDC nanofibers in addition to the carbon formed at $1500{ }^{\circ} \mathrm{C}$, because the CDC synthesis process does not remove initially formed carbon. ${ }^{\mathbf{1 6}}$ All Raman spectra (Fig. 2A) present two characteristic peaks for $\mathrm{sp}^{2}$-hybridized carbon, the $\mathrm{D}$ - and G-modes at around 1340 and $1600 \mathrm{~cm}^{-1}$ related to $\mathrm{sp}^{2}$-hybridized carbon atoms in rings and the presence of defects in this structure. ${ }^{46}$ Additionally, we see the corresponding combination and overtone modes between 2500 and $3500 \mathrm{~cm}^{-1}$. The position of the G-mode is shifted from 1603 to $1597 \mathrm{~cm}^{-1}$ when increasing the synthesis temperature from $400{ }^{\circ} \mathrm{C}$ to $900{ }^{\circ} \mathrm{C}$, due to the successive transformation from nanocrystalline into larger graphitic structures. ${ }^{46}$ This graphitization correlates well with the decrease in the intensity of the amorphous carbon phase (1500-1550 $\mathrm{cm}^{-1}$ ) with increasing temperature. ${ }^{46,47}$

For the analysis of the different carbon phases, a four Voigt peak deconvolution was applied to the Raman data (see ESI, Fig. $55 \dagger$ ). At $400{ }^{\circ} \mathrm{C}$ the $I_{\mathrm{D}} / I_{\mathrm{G}}$ ratio (i.e., the intensity ratio of the $\mathrm{D}$ - and G-mode peaks) is similar to that of the precursor (see ESI, Table S2 $\dagger$ ). At this temperature graphitic carbon, preserved from NbC-1500, co-exists with new partially amorphous/nanocrystalline CDC. At $600{ }^{\circ} \mathrm{C}$, the grain size of nanocrystalline CDC increases proportionally to the defect concentration in hexagonal carbon rings (higher $I_{\mathrm{D}} / I_{\mathrm{G}}$ ratio). ${ }^{46}$ By treatment at $900{ }^{\circ} \mathrm{C}$, the domains exceed a specific size (around $2 \mathrm{~nm}$ ), ${ }^{46}$ leading to graphitic carbon with less defects (lower $I_{\mathrm{D}} / I_{\mathrm{G}}$ ratio). The successive transformation from amorphous into graphitic carbon is further supported by the sharpening of the D-mode FWHM from $96.2 \pm 0.8 \mathrm{~cm}^{-1}$ to $82.8 \pm 3.6 \mathrm{~cm}^{-1}$ when increasing the synthesis temperature from 400 to $900{ }^{\circ} \mathrm{C}$.

XRD data (Fig. 2B) corroborate the transformation of $F m \overline{3} m$ niobium carbide after chlorine gas treatment into amorphous carbon at $400{ }^{\circ} \mathrm{C}$. While all crystalline niobium carbide peaks vanish, we observed a sharp (002)-graphite reflection $\left(\mathrm{P6}_{3} \mathrm{mc}\right)$ at around $26.5^{\circ} 2 \theta$ at $400^{\circ} \mathrm{C}$ corresponding to the graphitic carbon present in the precursor. When increasing the temperature, two broad peaks are observed at around 26.5 and $44^{\circ} 2 \theta$ related to the (002) and (110)-graphite reflections, ${ }^{48}$ related to the transformation of the formed amorphous or nanocrystalline phase into graphitic carbon.

The pore structure of the material was analyzed before and after $\mathrm{Cl}_{2}$ treatment by nitrogen gas sorption analysis (Fig. $2 \mathrm{C}$ and D). NbC-1500 presents a type I(b) isotherm, ${ }^{49}$ with mainly micropores with an average size of $1.2 \mathrm{~nm}$. With non-porous NbC nanocrystals, this porosity is completely accomplished by microporous carbon in the hybrid nanofibers. After $\mathrm{Cl}_{2}$ treatment, the surface area is drastically increased from $120 \mathrm{~m}^{2} \mathrm{~g}^{-1}$ to maximum $1370 \mathrm{~m}^{2} \mathrm{~g}^{-1}$ (DFT SSA) and the pore volume from $0.06 \mathrm{~cm}^{3} \mathrm{~g}^{-1}$ to $1.0 \mathrm{~cm}^{3} \mathrm{~g}^{-1}$ (Table 1 ). The removal of $\mathrm{Nb}$ from the $\mathrm{NbC}$ crystal lattice at $400{ }^{\circ} \mathrm{C}$ for $1 \mathrm{~h}$ led to the formation of microand meso-pores (below $3 \mathrm{~nm}$; see ESI, Fig. S4D $\dagger$ ), with a mean pore size of $1.8 \mathrm{~nm}$. At $600{ }^{\circ} \mathrm{C}$ for $1 \mathrm{~h}$, more micropores are formed (below $2 \mathrm{~nm}$ ), related to a higher amount of $\mathrm{Nb}$ etching compared to that at $400{ }^{\circ} \mathrm{C}$, and a mean pore size of $1.1 \mathrm{~nm}$ was obtained. At a higher temperature $\left(900{ }^{\circ} \mathrm{C}\right.$ for $\left.1 \mathrm{~h}\right)$ the redistribution of carbon slightly increases the mean pore size $(1.2 \mathrm{~nm})$. The isotherms after treatment for $1 \mathrm{~h}$ correspond to a type $\mathrm{I}(\mathrm{b})$ isotherm, with mainly micropores (see ESI, Fig. S4C $\dagger$ ). ${ }^{49}$ When increasing the time to $3 \mathrm{~h}$, all the isotherms become type II because of pore growth, while maintaining a type $\mathrm{I}(\mathrm{b})$ shape at low pressures. The change to the type II isotherm comes with an H4 hysteresis loop related to capillary condensation ${ }^{49}$ and a broader distribution of mesopores. The increase in the pore size when increasing the synthesis time leads to a decrease in the surface area and an increase in the pore volume (Table 1).

Electrochemical performance. For electrochemical evaluation of CDC nanofibers (treated for $3 \mathrm{~h}$ ), a half-cell setup was initially used. For comparison, the electrochemical performance of samples treated for $1 \mathrm{~h}$ is presented in the ESI (Fig. S6 $\dagger$ ). The measured cyclic voltammograms (Fig. 3A) show the overall 

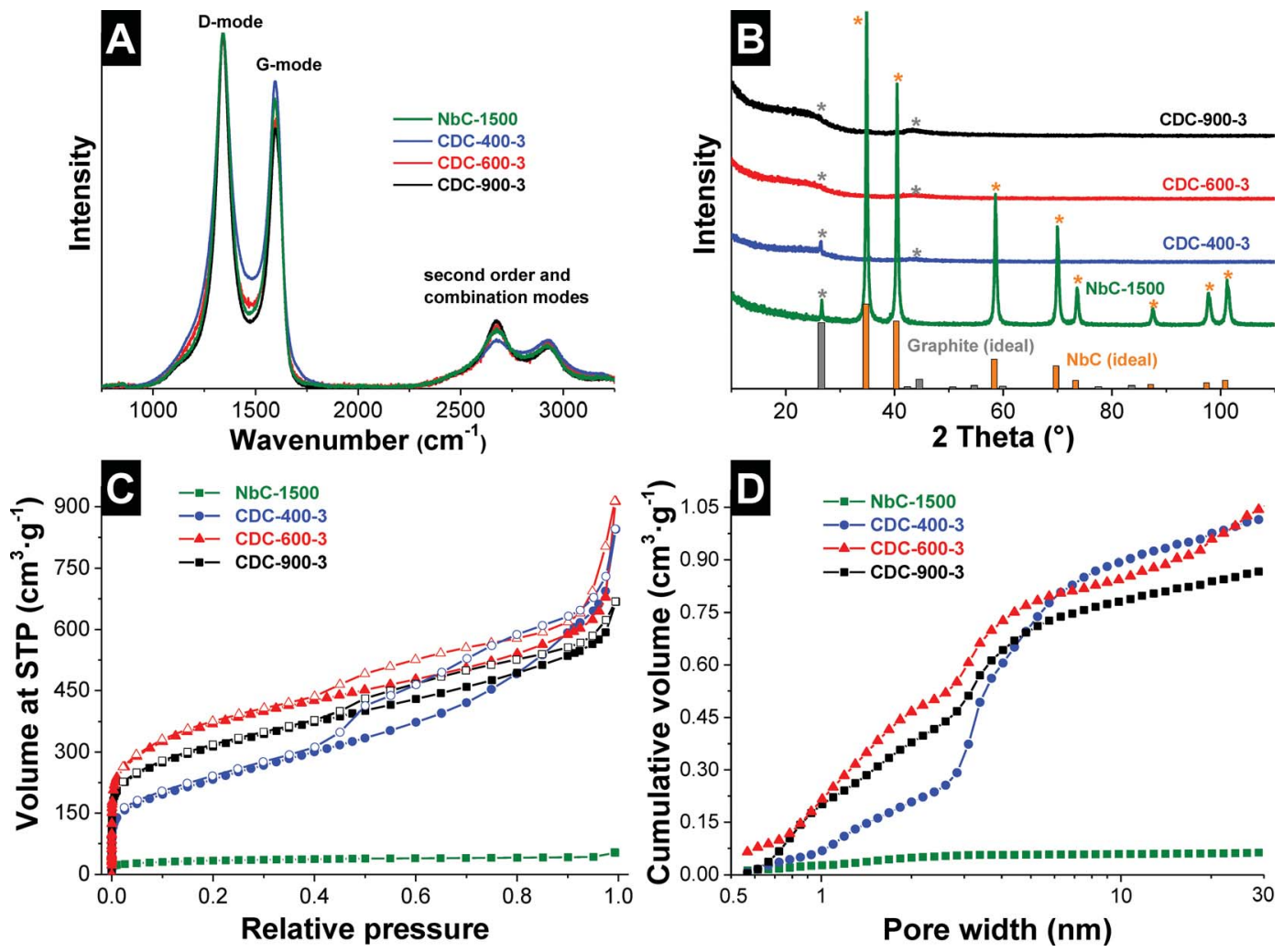

Fig. 2 Structural characterization of $\mathrm{NbC}-1500$ fibers before and after chlorine treatment for $3 \mathrm{~h}$. (A) Raman spectra, (B) XRD diffractograms and literature values of the diffraction peak positions of NbC (PDF: 38-1364) and graphite (PDF: 89-8487), (C) isotherms from nitrogen gas sorption at $-196{ }^{\circ} \mathrm{C}$ (STP: standard temperature pressure), and (D) cumulative pore volume as a function of the pore width from QSDFT deconvolution.

rectangular shape, which is characteristic of electric double-layer capacitance. ${ }^{5}$ We also see an increase of the capacitance when the voltage is increased. This well-known effect is related to electrochemical doping..$^{50}$ The data presented in Fig. 3B depict the difference in specific capacitance at positive or negative polarization, that is, anion or cation electrosorption. For example, it is observed that for CDC-600-1 the capacitance at negative and positive polarization corresponds to 87 and $108 \mathrm{~F} \mathrm{~g}^{-1}$, respectively (see ESI, Fig. S6B $\dagger$ ). By treatment at $600{ }^{\circ} \mathrm{C}$ for $3 \mathrm{~h}$, capacitance values of 102 and $115 \mathrm{~F} \mathrm{~g}^{-1}$ were achieved at negative and positive polarization. The lower capacitance values at negative voltage relate to the larger size of $\mathrm{TEA}^{+}$compared to $\mathrm{BF}_{4}{ }^{-}{ }^{51,52}$

Full-cell performance was evaluated by cyclic voltammetry and galvanostatic cycling. The CVs (Fig. 3C) present a typical rectangular shape, with a typical increase in the capacitance when increasing the applied voltage. At $2.7 \mathrm{~V}$, maximum values are achieved between 90 and $125 \mathrm{~F} \mathrm{~g}^{-1}$. Rate handling for fullcells was characterized by galvanostatic cycling to $2.5 \mathrm{~V}$ cell voltage. At a specific current of $0.02 \mathrm{~A} \mathrm{~g}^{-1}$, capacitance values between 64 and $83 \mathrm{~F} \mathrm{~g}^{-1}$ were obtained for the samples with the lowest SSA (CDC-400-3 and CDC-900-3) (Table 2). The highest capacitance was achieved for the samples synthesized at $600{ }^{\circ} \mathrm{C}\left(101-108 \mathrm{~F} \mathrm{~g}^{-1}\right.$ for 1-3 $\mathrm{h}$ of chlorine gas treatment; see Fig. 3D and Table 2). When increasing the specific current to $0.1 \mathrm{~A} \mathrm{~g}^{-1}$, most of the samples present a decrease in capacitance between 10 and 20\%. CDC-900-3, which presents a larger mean pore size $(2.6 \mathrm{~nm})$, maintained at $0.1 \mathrm{~A} \mathrm{~g}^{-1} 97 \%$ of the capacitance at $0.02 \mathrm{~A} \mathrm{~g}^{-1}$. At a very high specific current of $40 \mathrm{~A} \mathrm{~g}^{-1}$, all samples retained still between 44 and $56 \%$ of the initial capacitance. Compared to other CDC materials, the

Table 1 Results from the gas sorption analysis using nitrogen at $-196{ }^{\circ} \mathrm{C}$

\begin{tabular}{lllll}
\hline Sample & DFT SSA $\left(\mathrm{m}^{2} \mathrm{~g}^{-1}\right)$ & BET SSA $\left(\mathrm{m}^{2} \mathrm{~g}^{-1}\right)$ & Pore volume $\left(\mathrm{cm}^{3} \mathrm{~g}^{-1}\right)$ & Mean pore size $(\mathrm{nm})$ \\
\hline NbC-1500 & 122 & 121 & 0.06 & 1.2 \\
CDC-400-1 & 1065 & 1141 & 0.78 & 1.8 \\
CDC-400-3 & 744 & 750 & 1.00 & 3.5 \\
CDC-600-1 & 1369 & 1508 & 0.80 & 1.1 \\
CDC-600-3 & 1207 & 1326 & 0.96 & 2.4 \\
CDC-900-1 & 1092 & 1123 & 0.63 & 1.2 \\
CDC-900-3 & 980 & 1122 & 0.87 & 2.6
\end{tabular}



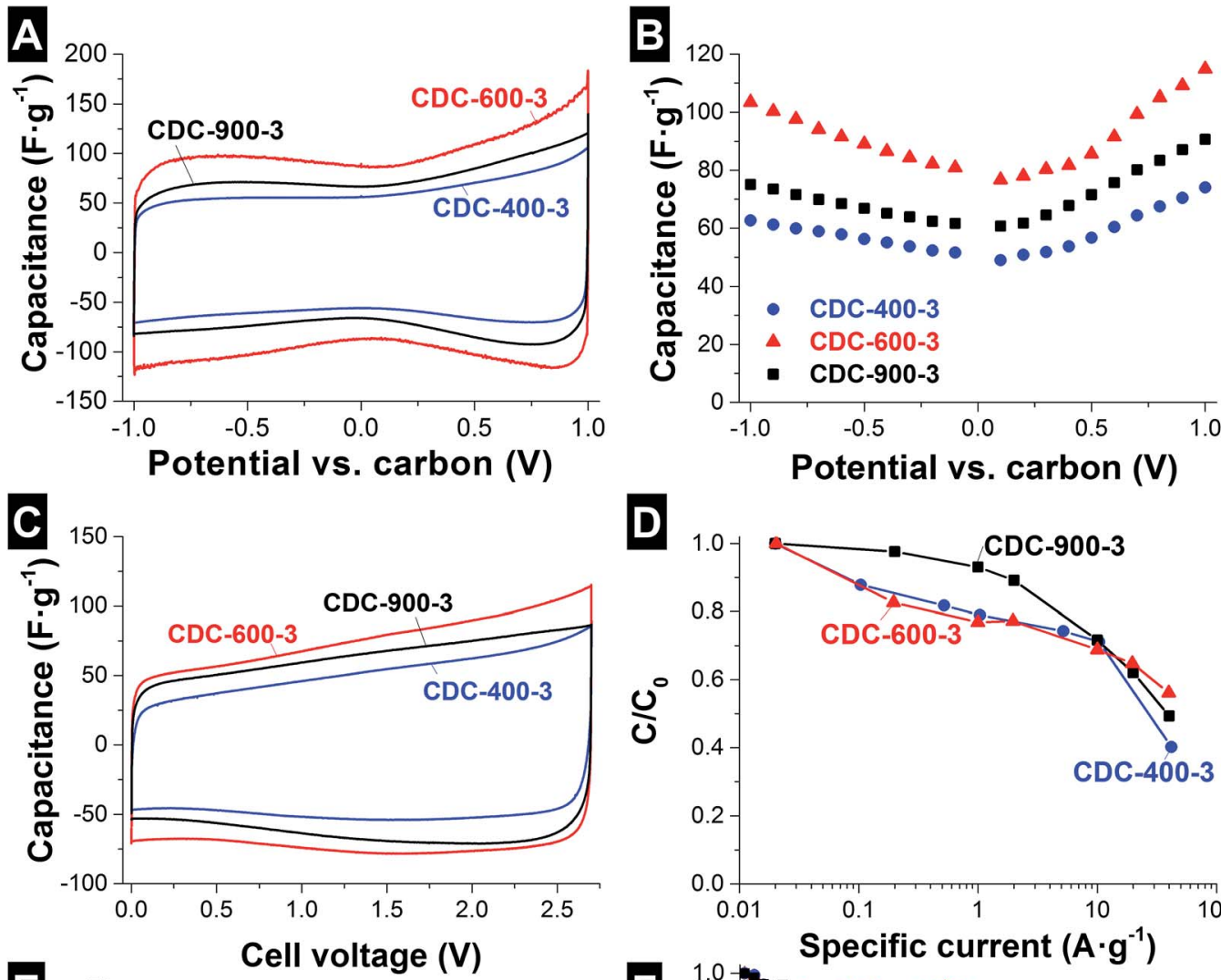

D

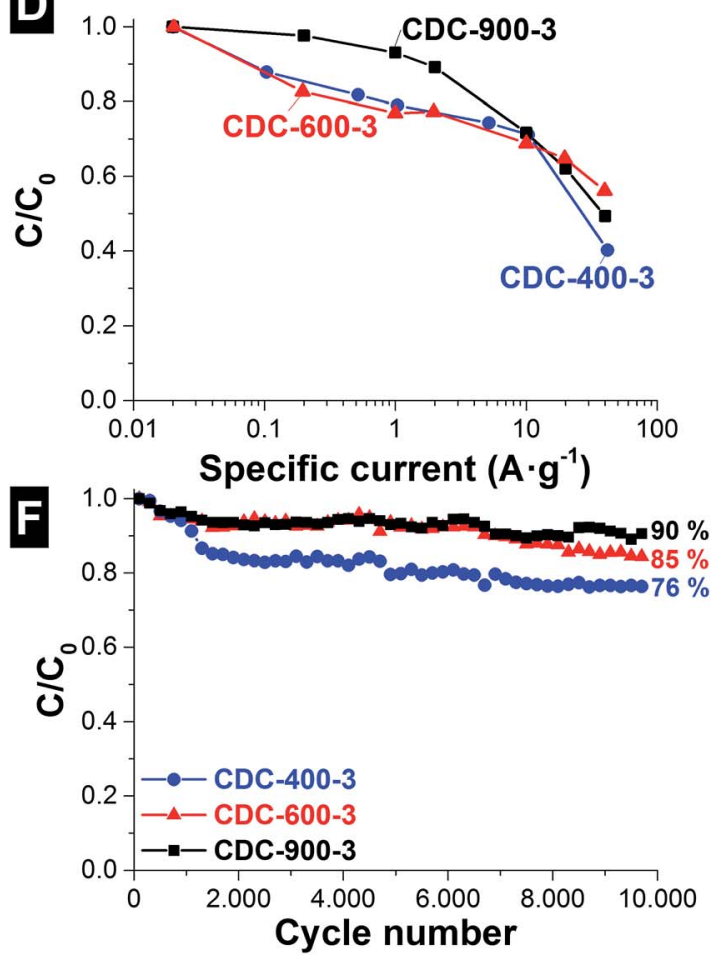

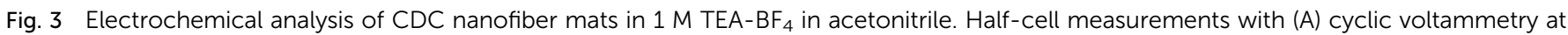
$10 \mathrm{mV} \mathrm{s}^{-1}$ and (B) GCPL profiles at $2 \mathrm{~A} \mathrm{~g}^{-1}$. Full-cell measurements using (C) cyclic voltammetry at $10 \mathrm{mV} \mathrm{s}^{-1}$, (D) GCPL power handling between 0.02 and $40 \mathrm{~A} \mathrm{~g}^{-1}$ (d), (E) electrochemical impedance spectra, and (F) galvanostatic cycling stability up to $2.5 \mathrm{~V}$ cell voltage at $1 \mathrm{~A} \mathrm{~g}^{-1}$.

electrochemical performance and energy storage capacity of NbC-CDC-600 in an organic electrolyte are good, as seen from Table 3. Compared to commercial electrodes (AC $+5 \%$ PTFE), NbC-CDC-600 presents similar capacitance values $\left(104 \mathrm{~F} \mathrm{~g}^{-1}\right)$, but a superior capacitance retention above $10 \mathrm{~A} \mathrm{~g}^{-1}$ related to the excellent charge propagation in the continuous fiber network.

To further characterize the electrochemical behavior, impedance spectroscopy (EIS) was carried out for full-cells (Fig. 3E). As seen from the inset in Fig. 3E, the evolving semicircle correlates with a high contact resistance between the fibers and the current collector. Compared to free-standing polymer-bound carbon electrodes, fiber electrodes are less smooth at the interface with the current collector, which is why an additional contact impedance arises. ${ }^{18,53}$ At very low frequencies, the constant phase element (CPE) is close to 1 with values from 0.89 to 0.97 indicative of a near-ideal capacitive behavior (Table 2). ${ }^{53}$ Furthermore a direct correlation between the degree of carbon ordering, the pore structure, and the rate handling performance (Table 2) is observed. The samples with the highest degree of carbon ordering lead to the lowest equivalent serial resistance (ESR), namely the samples $\mathrm{Cl}_{2}$ treated at higher temperatures and times, CDC-600-3, CDC-900-1 and CDC-900-3 (43-53 $\left.\Omega \mathrm{cm}^{2}\right)$.

The stability of the system was benchmarked by galvanostatic cycling (Table 2). Most of the samples retain more than $80 \%$ of the initial capacitance after 10000 charge/discharge cycles. The only exception is CDC-400-3 with a capacitance loss 
Table 2 Electrochemical performance of $\mathrm{NbC}-\mathrm{CDC}$ fibers

\begin{tabular}{|c|c|c|c|c|c|c|}
\hline Sample & $\operatorname{ESR}\left(\Omega \mathrm{cm}^{2}\right)$ & $\operatorname{EDR}\left(\Omega \mathrm{cm}^{2}\right)$ & CPE exponent & $C\left(\mathrm{~F} \mathrm{~g}^{-1}\right)$ at $0.02 \mathrm{~A} \mathrm{~g}^{-1}$ & $\begin{array}{l}C \text { loss }(\%) \\
\text { at } 40 \mathrm{~A} \mathrm{~g}^{-1}\end{array}$ & $\begin{array}{l}C / C_{0}(\%) \text { after } \\
10000 \text { cycles }\end{array}$ \\
\hline CDC-400-1 & 0.89 & 0.16 & 0.95 & 97 & 68 & 85 \\
\hline CDC-600-1 & 0.78 & 0.18 & 0.93 & 101 & 80 & 91 \\
\hline CDC-600-3 & 0.53 & 0.45 & 0.94 & 108 & 44 & 85 \\
\hline CDC-900-1 & 0.47 & 0.21 & 0.96 & 85 & 56 & 92 \\
\hline
\end{tabular}

of $24 \%$. The highest capacitance retention was found for CDC600-1 (91\%) and CDC-900-1 or CDC-900-3 (90-92\%). This enhanced stability may be related to the lower content of oxygen containing functional groups (Table S1†).

\section{Niobium pentoxide-carbon hybrid nanofibers}

Material characterization. For the synthesis of $\mathrm{Nb}_{2} \mathrm{O}_{5} / \mathrm{C}$ hybrid nanofibers, starting from NbC-1700, first suitable synthesis conditions (atmosphere, temperature, and time) were surveyed by TGA and in situ Raman spectroscopy (see ESI, Fig. S7A and $\mathrm{B} \dagger$ ). Thermodynamic calculations (see ESI, Fig. S7C and $\mathrm{D}^{\dagger}$ ) indicate that $\mathrm{Nb}_{2} \mathrm{O}_{5}$ is the stable metal oxide phase within the entire studied temperature range (i.e., up to $1000{ }^{\circ} \mathrm{C}$ ) in either $\mathrm{CO}_{2}$ or $\mathrm{O}_{2}$ atmospheres. Depending on the degree of ordering, we expect for nanoporous carbon an onset of oxidation at around $400-650{ }^{\circ} \mathrm{C.}^{22}$ From the literature, we would expect an initial onset of $\mathrm{NbC}$ oxidation at around $450{ }^{\circ} \mathrm{C}$ in $\mathrm{O}_{2} \cdot{ }^{54}$ Thus, the challenge is to find suitable conditions at which $\mathrm{NbC}$ is effectively oxidized to $\mathrm{Nb}_{2} \mathrm{O}_{5}$ without completely oxidizing solid carbon.

To identify the most suitable processing parameters, we employed thermogravimetric analysis. In $\mathrm{CO}_{2}$ at $5{ }^{\circ} \mathrm{C} \mathrm{min}{ }^{-1}$, we see an onset of mass increase at $720^{\circ} \mathrm{C}$, reaching a maximum at $950{ }^{\circ} \mathrm{C}(+12 \%)$. Further temperature increase resulted in a progressing mass loss associated with the burn-off of carbon. In this range of temperatures, $\mathrm{T}-\mathrm{Nb}_{2} \mathrm{O}_{5}$ formation is expected ${ }^{36,55}$ as the only crystalline phase in co-existence with carbon. Therefore, $850{ }^{\circ} \mathrm{C}$ was selected as the preferred temperature for treatment under $\mathrm{CO}_{2}$ to produce the hybrid material.

Using synthetic air, the volatilization of carbon occurs at lower temperatures, at around $500{ }^{\circ} \mathrm{C}$ (see ESI, Fig. S7A $\dagger$ ), and at similar temperatures to that of the carbide oxidation, at around $450{ }^{\circ} \mathrm{C}$. At $410{ }^{\circ} \mathrm{C}$, the mass of the system increases related to oxidation of the $\mathrm{NbC}$, reaching a maximum at $460{ }^{\circ} \mathrm{C}(+20 \%)$. At higher temperatures, carbon burning takes place (TGA derivate peak, $590{ }^{\circ} \mathrm{C}$ ) leading to mass decrease. In alignment with these data and the literature, the only expected crystalline phase in this temperature range is TT- $\mathrm{Nb}_{2} \mathrm{O}_{5} \cdot{ }^{36,55}$ For a better identification of an optimum temperature for the treatment in air, we carried out in situ Raman measurements (see ESI, Fig. S7B $\dagger$ ). In situ Raman spectra show the emergence of niobia-related signals $\left(646 \text { to } 670 \mathrm{~cm}^{-1}\right)^{56}$ for temperatures above $600{ }^{\circ} \mathrm{C}$ and the decrease in carbon signal intensities for the D- and G-mode peaks at 1323 and $1575 \mathrm{~cm}^{-1}$, respectively. To avoid the enhanced loss of carbon, lower synthesis temperatures in air were chosen, namely $450{ }^{\circ} \mathrm{C}$ and $500{ }^{\circ} \mathrm{C}$.

After treatment under $\mathrm{CO}_{2}\left(850^{\circ} \mathrm{C}\right)$ or air $\left(450\right.$ and $\left.500{ }^{\circ} \mathrm{C}\right)$, the sample mass increased between 7 and 38\% (Table 4). Yet, the nanofiber morphology was fully maintained, as seen from the SEM micrographs in Fig. 4. Image analysis documents an increase in the average fiber diameter by $55 \%(87 \pm 25 \mathrm{~nm}$; see ESI, Fig. S8 $\dagger$ ), related to the difference in density between $\mathrm{NbC}$ and $\mathrm{Nb}_{2} \mathrm{O}_{5}$ (7.8 and $4.6 \mathrm{~g} \mathrm{~cm}^{-3}$, respectively). ${ }^{57}$ In the TEM micrographs (Fig. 4A, inset), only highly amorphous material was identified for the samples synthesized in air at $450{ }^{\circ} \mathrm{C}$. The corresponding SAED pattern confirms the highly disordered nature of the material at $450{ }^{\circ} \mathrm{C}$. Nanocrystalline TT- $\mathrm{Nb}_{2} \mathrm{O}_{5}$ domains emerge when using a higher synthesis temperature $\left(500{ }^{\circ} \mathrm{C}\right)$ while the majority of the diffraction signal is still indicative of a highly amorphous material. Higher temperatures are required to obtain a well-developed $\mathrm{TT}-\mathrm{Nb}_{2} \mathrm{O}_{5}$ crystal structure. However, at $500{ }^{\circ} \mathrm{C}$, already a strong oxidation of

Table 3 Comparison among different reported carbide-derived carbon materials and commercial powder electrodes, characterized for electrical double-layer capacitors

\begin{tabular}{|c|c|c|c|c|c|}
\hline Sample & BET-SSA $\left(\mathrm{m}^{2} \mathrm{~g}^{-1}\right)$ & $\begin{array}{l}\text { Pore volume } \\
\left(\mathrm{cm}^{3} \mathrm{~g}^{-1}\right)\end{array}$ & $C\left(\mathrm{~F} \mathrm{~g}^{-1}\right)$ & Capacitance retention & Reference \\
\hline NbC-CDC fibers & 1508 & 0.80 & 101 & $20 \%$ at $40 \mathrm{~A} \mathrm{~g}^{-1}$ & 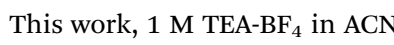 \\
\hline NbC-CDC fibers & 1326 & 0.96 & 108 & $56 \%$ at $40 \mathrm{~A} \mathrm{~g}^{-1}$ & This work, $1 \mathrm{M}$ TEA-BF 4 in ACN \\
\hline SiC-CDC particles & 2430 & 1.50 & 125 & $85 \%$ at $20 \mathrm{~A} \mathrm{~g}^{-1}$ & Ref. $191 \mathrm{M}$ TEA-BF 4 in ACN \\
\hline SiC-CDC particles & 2250 & 1.40 & 160 & $81 \%$ at $20 \mathrm{~A} \mathrm{~g}^{-1}$ & Ref. $19,1 \mathrm{M}$ TEA-BF 4 in ACN \\
\hline SiOC-CDC fibers & 3089 & 1.78 & 135 & $63 \%$ at $50 \mathrm{~A} \mathrm{~g}^{-1}$ & Ref. $18,1 \mathrm{M}$ TEA-BF 4 in ACN \\
\hline SiOC-CDC particles & 2480 & 1.29 & 110 & $83 \%$ at $30 \mathrm{~A} \mathrm{~g}^{-1}$ & Ref. $61,1 \mathrm{M}$ TEA-BF 4 in ACN \\
\hline TiC-CDC fibers & 1390 & 1.50 & 102 & $50 \%$ at $5 \mathrm{~V} \mathrm{~s}^{-1}$ & Ref. $12,1.5 \mathrm{M} \mathrm{TEA}^{-\mathrm{BF}_{4}}$ in ACN \\
\hline $\mathrm{AC}+5 \%$ PTFE & 1481 & 0.8 & 104 & $68 \%$ at $10 \mathrm{~A} \mathrm{~g}^{-1}$ & Ref. $62,1.0 \mathrm{M} \mathrm{TEA}^{-\mathrm{BF}_{4}}$ in ACN \\
\hline
\end{tabular}


Table 4 EDX results of $\mathrm{Nb}_{2} \mathrm{O}_{5} / \mathrm{C}$ hybrid nanofibers, and mass change measured after thermal treatment in air or $\mathrm{CO}_{2}$

\begin{tabular}{llrrr}
\hline Sample & Mass change & $\mathrm{C}(\mathrm{mass} \%)$ & $\mathrm{O}(\mathrm{mass} \%)$ & $\mathrm{Nb}$ (mass\%) \\
\hline $\mathrm{NbC}-1700$ & - & $27.6 \pm 0.5$ & $2.0 \pm 0.1$ & $70.3 \pm 1.1$ \\
$\mathrm{Nb}_{2} \mathrm{O}_{5}-450$ & $+16 \%$ & $11.8 \pm 0.7$ & $27.8 \pm 1.3$ & $60.4 \pm 1.2$ \\
$\mathrm{Nb}_{2} \mathrm{O}_{5}-500$ & $+7 \%$ & $8.9 \pm 0.6$ & $28.8 \pm 1.9$ & $62.4 \pm 1.9$ \\
$\mathrm{Nb}_{2} \mathrm{O}_{5}-850$ & $+38 \%$ & $18.6 \pm 0.8$ & $25.0 \pm 1.2$ & $56.4 \pm 1.0$
\end{tabular}

carbon takes place as observed from the change in the carbon content according to the EDX data (Table 4). Therefore, a less oxidative environment was chosen in alignment with theoretical calculation, namely thermal treatment in $\mathrm{CO}_{2}$ (see ESI, Fig. S7A $\dagger$ ). At $850{ }^{\circ} \mathrm{C}$, TEM micrographs show $\mathrm{Nb}_{2} \mathrm{O}_{5}$ nanocrystals engulfed in graphitic carbon (Fig. 4C). The corresponding SAED pattern is characteristic of a highly crystalline material, with diffraction patterns falling into almost continuous rings related to $\mathrm{T}-\mathrm{Nb}_{2} \mathrm{O}_{5}$.

For a more detailed characterization of the crystal structure of the synthesized materials, XRD patterns and Raman spectra were recorded (Fig. 5). All Raman spectra indicate the presence of partially graphitic carbon in all samples. Yet, the carbon signal was very high for $\mathrm{NbC}-1700$ and almost identical to that of $\mathrm{Nb}_{2} \mathrm{O}_{5}-850$. The apparent absence of clear signals from crystalline niobia in $\mathrm{Nb}_{2} \mathrm{O}_{5}-850$ is related to the very high sensitivity of Raman spectroscopy to detect $\mathrm{sp}^{2}$-hybridized carbon species. ${ }^{58}$ In contrast, the $\mathrm{TT}-\mathrm{Nb}_{2} \mathrm{O}_{5}$ signal and the fluorescence-related background were stronger after oxidation in air. Yet, there are differences also related to the carbon signal as seen after peak deconvolution (see ESI, Table S3†). For $\mathrm{Nb}_{2} \mathrm{O}_{5}-450$, we found broader $\mathrm{D}$ - and G-peaks compared to the precursor and an overall increase in the amount of amorphous carbon (see ESI, Fig. S9†) as a result of on-setting carbon oxidation. The high fluorescence background for $\mathrm{Nb}_{2} \mathrm{O}_{5}-500$ made peak deconvolution unreliable, but there was still a redshift of the G-mode peak from 1599 to $1584 \mathrm{~cm}^{-1}$ due to the co-existing amorphous phase. According to the mass change during the process and EDX results (Table 4), the carbon content drastically decreased for this sample.

According to the XRD pattern (Fig. 5B), NbC is transformed after treatment in an oxidative atmosphere into a highly amorphous material for $\mathrm{Nb}_{2} \mathrm{O}_{5}-450$ and into nanocrystalline niobium pentoxide for $\mathrm{Nb}_{2} \mathrm{O}_{5}-500$ and $\mathrm{Nb}_{2} \mathrm{O}_{5}-850$. By applying the Scherrer equation, ${ }^{41}$ in air at $500{ }^{\circ} \mathrm{C}, \mathrm{TT}^{\mathrm{T}}-\mathrm{Nb}_{2} \mathrm{O}_{5}$ is formed with an average domain size of $c a .20 \mathrm{~nm}$ and lattice parameters, $a=0.36 \mathrm{~nm}, b=0.31 \mathrm{~nm}$, and $c=0.39 \mathrm{~nm}$. By treatment in $\mathrm{CO}_{2}$ at $850{ }^{\circ} \mathrm{C}$, orthorhombic $\mathrm{T}-\mathrm{Nb}_{2} \mathrm{O}_{5}$ is formed with an average domain size of $c a .35 \mathrm{~nm}$ and lattice parameters, $a=0.62 \mathrm{~nm}$, $b=2.93 \mathrm{~nm}$, and $c=0.39 \mathrm{~nm}$.

Electrochemical performance. $\mathrm{Nb}_{2} \mathrm{O}_{5} / \mathrm{C}$ hybrid nanofibers were evaluated for $\mathrm{Li}^{+}$ion intercalation. It has been already reported that anodic and cathodic peaks related to $\mathrm{Li}^{+}$ion intercalation-deintercalation are located between 1.0 and $2.0 \mathrm{~V} v s$. $\mathrm{Li} / \mathrm{Li}^{+}$(between -2.4 and $-1.4 \mathrm{~V}$ vs. carbon), ${ }^{36}$ and in this potential window $\mathrm{LiClO}_{4}$ in EC/DMC presents a high coulombic efficiency and stability, ${ }^{37}$ and therefore this electrolyte was
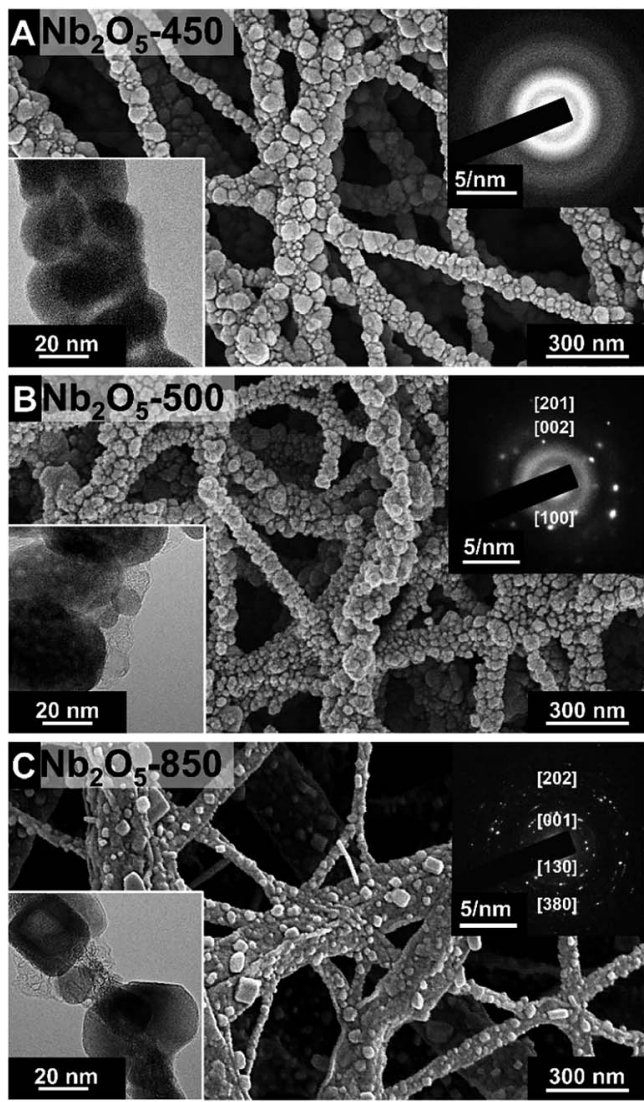

Fig. 4 SEM micrographs, TEM micrographs (inset, lower left corner), and selected area electron diffraction pattern (inset, upper right corner) of $\mathrm{Nb}_{2} \mathrm{O}_{5} / \mathrm{C}$ hybrid nanofibers synthetized at $(\mathrm{A}) 450{ }^{\circ} \mathrm{C}$ in air, (B) $500{ }^{\circ} \mathrm{C}$ in air, and (C) $850{ }^{\circ} \mathrm{C}$ in $\mathrm{CO}_{2}$.

selected. Electrochemical testing for half-cells was performed by $\mathrm{CV}$ at $1 \mathrm{mV} \mathrm{s}^{-1}$ to first confirm the potential at which the $\mathrm{Li}^{+}$ion intercalation takes place. From the CV shapes (Fig. 6A), a minor electric double-layer contribution to the energy storage is observed for all samples, since the fibers present a low SSA (around $82 \mathrm{~m}^{2} \mathrm{~g}^{-1}$ DFT SSA). $\mathrm{Nb}_{2} \mathrm{O}_{5}-450$ does not present visible redox intercalation peaks due to the amorphous character of $\mathrm{Nb}_{2} \mathrm{O}_{5} \cdot \mathrm{Nb}_{2} \mathrm{O}_{5}-500$ presents a broad increase in anodic current below $-0.8 \mathrm{~V} v$ s. carbon, related to the slow diffusion and intercalation process. A high specific cathodic current below $-0.5 \mathrm{~V} v s$. carbon is related to the slow deintercalation of the $\mathrm{Li}^{+}$ ions. This indicates that $\mathrm{Li}^{+}$intercalation and deintercalation take place within a broad potential window due to kinetic effects and the co-existence of amorphous and low-order domains of $\mathrm{TT}-\mathrm{Nb}_{2} \mathrm{O}_{5}$. In the case of $\mathrm{Nb}_{2} \mathrm{O}_{5}-850, \mathrm{Li}^{+}$deintercalation takes place at $-1.2 \mathrm{~V}$, and the more pronounced peak is related to the enhanced intercalation kinetics of the $\mathrm{T}-\mathrm{Nb}_{2} \mathrm{O}_{5}$ crystal structure. These results are also confirmed by the voltage plateau observed by GCPL (see ESI, Fig. S10A $\dagger$ ). $\mathrm{Li}^{+}$ intercalation takes place in two steps, as shown by the anodic peaks at -1.3 and $-1.5 \mathrm{~V} v s$. carbon. At these potentials, peak currents are higher for $\mathrm{T}-\mathrm{Nb}_{2} \mathrm{O}_{5}$ than for $\mathrm{TT}-\mathrm{Nb}_{2} \mathrm{O}_{5}$, suggesting a higher lithium intercalation capacity for this crystal phase. 

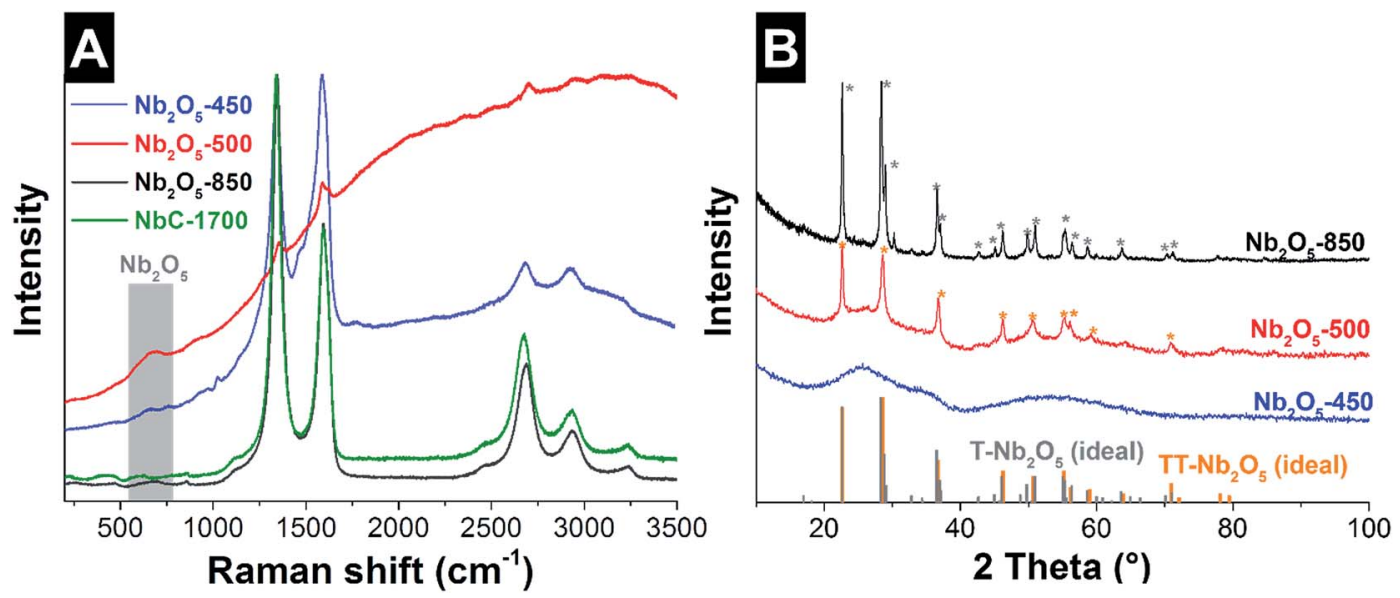

Fig. 5 (A) Raman spectra of $\mathrm{Nb}_{2} \mathrm{O}_{5} / \mathrm{C}$ hybrid nanofibers and the precursor ( $\mathrm{NbC}-1700$ ). (B) XRD diffractograms of $\mathrm{Nb}_{2} \mathrm{O}_{5} / \mathrm{C}$ hybrid nanofibers and literature values of diffraction peak positions of $\mathrm{T}-\mathrm{Nb}_{2} \mathrm{O}_{5}$ (PDF: 27-1003) and $\mathrm{TT}-\mathrm{Nb}_{2} \mathrm{O}_{5}$ (PDF: 07-0061).

The observed peaks are related to the electron transfer resulting from lithium intercalation according to the reaction in eqn (5), for redox couples $\mathrm{Nb}^{5+/ 4+}$ and $\mathrm{Nb}^{4+/ 3+} \cdot{ }^{36}$

$$
\mathrm{Nb}_{2} \mathrm{O}_{5}+x \mathrm{Li}^{+}+x \mathrm{e}^{-} \leftrightarrow \mathrm{Li}_{x} \mathrm{Nb}_{2} \mathrm{O}_{5}(x=1,2)
$$

By GCPL to $-2.0 \mathrm{~V}$ vs. carbon, the rate handling was evaluated for half-cells (Fig. 6B). The specific capacities of the third discharge cycle at $0.1 \mathrm{~A} \mathrm{~g}^{-1}$ for $\mathrm{Nb}_{2} \mathrm{O}_{5}-450, \mathrm{Nb}_{2} \mathrm{O}_{5}-500$ and $\mathrm{Nb}_{2} \mathrm{O}_{5}-850$ (1 C-rate), were 6, 101, and $156 \mathrm{~mA} \mathrm{~h} \mathrm{~g}{ }^{-1}$, respectively. When normalizing the results to the mass of niobium pentoxide, as commonly done for battery systems, we obtained capacities of $111 \mathrm{~mA} \mathrm{~h} \mathrm{~g}^{-1}$ and $191 \mathrm{~mA} \mathrm{~h} \mathrm{~g}^{-1}$ for $\mathrm{Nb}_{2} \mathrm{O}_{5}-500$ and $\mathrm{Nb}_{2} \mathrm{O}_{5}-850$, respectively. At $0.1 \mathrm{~A} \mathrm{~g}^{-1}$ the coulombic efficiency of $\mathrm{Nb}_{2} \mathrm{O}_{5}-500$ and $\mathrm{Nb}_{2} \mathrm{O}_{5}-850$ corresponds to 91 and $92 \%$, respectively. As presented in Table 5, these values are comparable to those reported in the literature for TT- $\mathrm{Nb}_{2} \mathrm{O}_{5}$ $\left(150 \mathrm{~mA} \mathrm{~h} \mathrm{~g}^{-1}\right.$ ) and $\mathrm{T}^{-} \mathrm{Nb}_{2} \mathrm{O}_{5}$ (between 142 and $190 \mathrm{~mA} \mathrm{~h} \mathrm{~g}{ }^{-1}$ ). At $20 \mathrm{~A} \mathrm{~g}^{-1}, 5 \%$ and $23 \%$ of the capacity were retained for $\mathrm{Nb}_{2} \mathrm{O}_{5}-500$ and $\mathrm{Nb}_{2} \mathrm{O}_{5}-850$, respectively. The higher rate handling performance of $\mathrm{Nb}_{2} \mathrm{O}_{5}-850$ is related not just to the graphitic carbon engulfing the $\mathrm{T}-\mathrm{Nb}_{2} \mathrm{O}_{5}$ crystals, but also to the short diffusion length in the nanofibers and the faster ionic transport characteristic of $\mathrm{T}-\mathrm{Nb}_{2} \mathrm{O}_{5}$. The latter was explained by Augustyn et al. by the almost empty octahedral sites between (001) planes presenting low energy barriers for $\mathrm{Li}^{+}$-ion transport throughout the $a-b$ plane. ${ }^{8}$

In order to benchmark $\mathrm{Nb}_{2} \mathrm{O}_{5} / \mathrm{C}$ hybrid nanofibers as a cathode (electrode at negative potentials) in a device, asymmetric full-cell tests were performed (Fig. 6C and D). As an anode (electrode at positive potentials), a charge balanced AC electrode was used. This set-up has demonstrated to improve the performance of the full-cell, by limiting the polarization resistance. ${ }^{31,59}$ For the CVs at $1 \mathrm{mV} \mathrm{s}^{-1}$, shown in Fig. 6C, a maximum applied cell voltage of $3.6 \mathrm{~V}$ was used, which was expected to lead to an appropriate operating potential range for positive and negative electrodes. For asymmetric full-cells, the different charge-voltage-behavior of the two electrodes led to asymmetric voltage development at the anode and cathode. Therefore, the voltage in each electrode was recorded by using an activated carbon spectator reference electrode (see ESI, Fig. S10B and $\mathrm{C} \dagger$ ). According to the $\mathrm{CV}$ (Fig. 6C) of $\mathrm{Nb}_{2} \mathrm{O}_{5}-500$, a cathodic peak can be observed at $2.5 \mathrm{~V}$ cell voltage and broad anodic peaks are detected at 1.8 and $2.8 \mathrm{~V}$ cell voltages. A strong increase in current close to $3.6 \mathrm{~V}$ cell voltage is related to fast voltage development at the positive electrode, above the potential limit for the stability of the electrolyte, and therefore the system is not stable. The voltage at the negative electrode reaches $-2.2 \mathrm{~V}$ vs. carbon, while for the positive electrode a voltage maximum of $1.4 \mathrm{~V}$ vs. carbon was obtained (see ESI, Fig. $\mathrm{S} 10 \mathrm{~B} \dagger$ ). For $\mathrm{Nb}_{2} \mathrm{O}_{5}-850$, at low voltage, a capacitive behavior was observed, related to the higher mass of AC present as the positive electrode, compared to $\mathrm{Nb}_{2} \mathrm{O}_{5}-500$. When increasing the cell voltage, $\mathrm{Li}^{+}$intercalation/deintercalation takes place in the $\mathrm{Nb}_{2} \mathrm{O}_{5}$ electrode, as indicated by broad anodic peaks between 2.2 and $1.8 \mathrm{~V}$ cell voltages, and cathodic peaks at 1.9 and $2.6 \mathrm{~V}$ cell voltages. At high cell voltage, the system is more stable than $\mathrm{Nb}_{2} \mathrm{O}_{5}-500$, and no strong increase in current is observed (see ESI, Fig. S10B $\dagger$ ).

The performance of full-cells was further characterized by GCPL to $3.6 \mathrm{~V}$ at $0.1 \mathrm{~A} \mathrm{~g}^{-1}$ (Fig. 6D). No significant charge storage in the cell is observed below $1.2 \mathrm{~V}$ and $1.6 \mathrm{~V}$ for $\mathrm{Nb}_{2} \mathrm{O}_{5}-850$ and $\mathrm{Nb}_{2} \mathrm{O}_{5}-500$, respectively, indicating no significant faradic charge transfer to the $\mathrm{Nb}_{2} \mathrm{O}_{5}$ electrode. Above this potential, a voltage plateau is observed for both samples, indicating a transfer of charge to the electrode when $\mathrm{Li}^{+}$ion intercalation takes place. From the voltage plateau during discharging and the difference in potential development for each electrode (see ESI, Fig. S10B $\dagger$ ), it can be concluded that both samples present a high difference in charge transfer efficiency. The coulombic efficiency of $\mathrm{Nb}_{2} \mathrm{O}_{5}-500$ and $\mathrm{Nb}_{2} \mathrm{O}_{5}-850$ corresponds to 40 and $80 \%$ respectively, for asymmetric fullcells. 

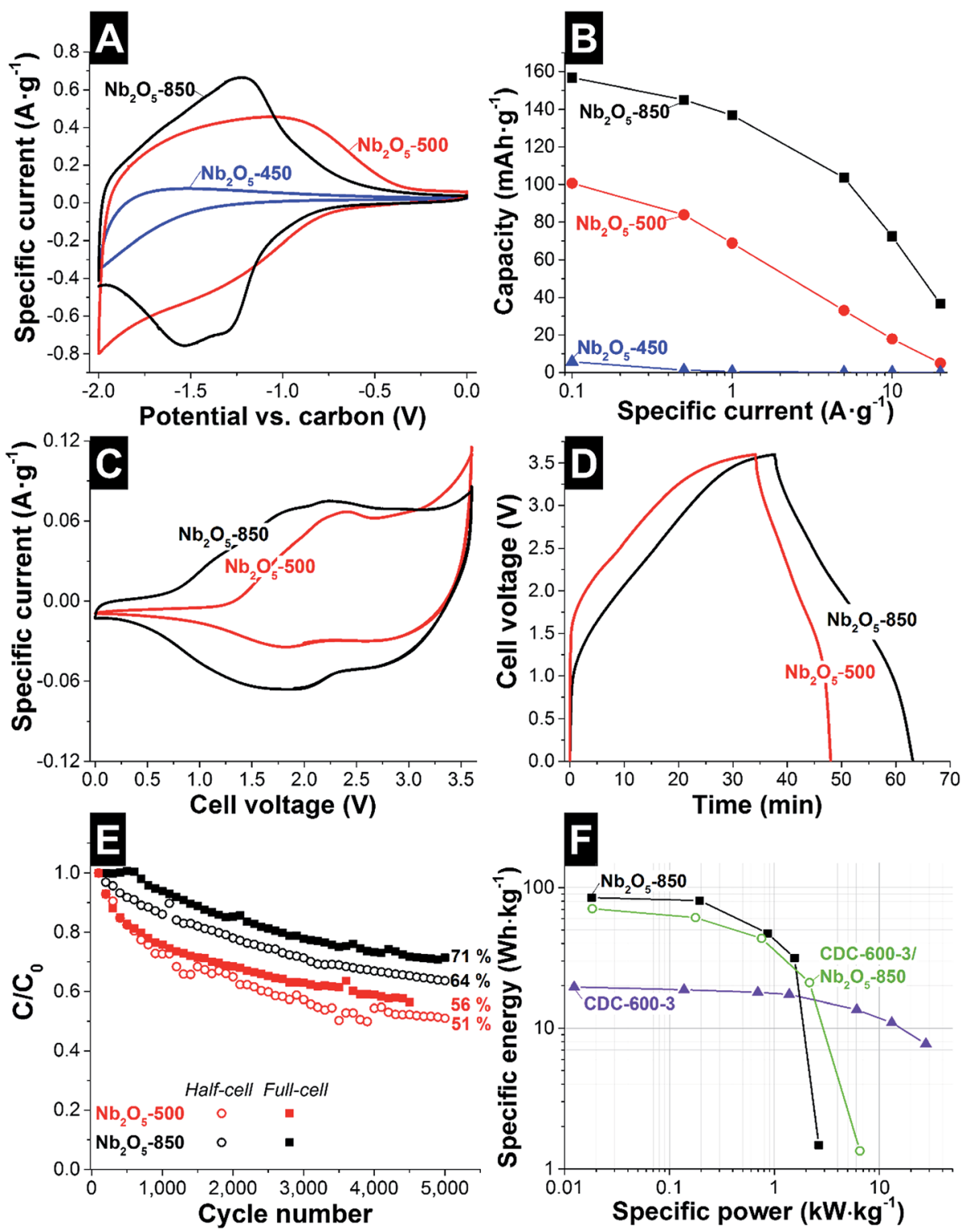

Fig. 6 Electrochemical characterization in the half-cell configuration of $\mathrm{Nb}_{2} \mathrm{O}_{5} / \mathrm{C}$ hybrid nanofibers in $1 \mathrm{M} \mathrm{LiClO}_{4}$ in $\mathrm{EC} / \mathrm{DMC}$ using (A) cyclic voltammetry at $1 \mathrm{mV} \mathrm{s}^{-1}$ and (B) galvanostatic charge/discharge rate handling to $-2 \mathrm{~V} v$ s. carbon. Electrochemical characterization in the full-cell configuration using (C) cyclic voltammetry up to $3.6 \mathrm{~V}$ cell voltage at $1 \mathrm{mV} \mathrm{s}^{-1}$ and (D) GCPL charge/discharge profile at $0.1 \mathrm{~A} \mathrm{~g}{ }^{-1}$. (E) Capacity retention during galvanostatic charge/discharge cycling to $3.0 \mathrm{~V}$ cell voltage for full-cells or from 0 to $-2 \mathrm{~V} v$ s. carbon for the half-cell configuration. (F) Ragone plot of full-cells.

Cycling stability tests were performed in half- and full-cell configurations (Fig. 6E). After 5000 cycles, $\mathrm{Nb}_{2} \mathrm{O}_{5}-850$ retained $64 \%$ and $71 \%$ of the capacity, in half- and full-cell setups, respectively. For $\mathrm{Nb}_{2} \mathrm{O}_{5}-850$, the lower stability of half-cells is related to the higher voltage $(-2.0 \mathrm{~V}$ for half-cells; $3.0 \mathrm{~V}$ for fullcells) and the high stability of the positive material, AC. For $\mathrm{Nb}_{2} \mathrm{O}_{5}-500,51 \%$ of the capacity was retained for the half-cell, while for the full-cell, $56 \%$ was maintained. The lower stability is related to the low order of crystallinity of the TT- $\mathrm{Nb}_{2} \mathrm{O}_{5}$.

The materials with the best electrochemical performance for electrical double-layer capacitors and battery-like systems are plotted in the Ragone plot (Fig. 6F). CDC-600-3 presents high power handling, maintaining a specific energy of $7.6 \mathrm{~W} \mathrm{~h} \mathrm{~kg}^{-1}$ at $30 \mathrm{~kW} \mathrm{~kg}^{-1}$ and a maximum specific energy of $19.5 \mathrm{~W} \mathrm{~h} \mathrm{~kg}^{-1}$ at $0.01 \mathrm{~kW} \mathrm{~kg}^{-1}$. For $\mathrm{Nb}_{2} \mathrm{O}_{5}-850$ asymmetric full-cells, a specific energy of $86 \mathrm{~W} \mathrm{~h} \mathrm{~kg}^{-1}$ at $0.02 \mathrm{~kW} \mathrm{~kg}^{-1}$ was exhibited. At $1.5 \mathrm{~kW} \mathrm{~kg}^{-1}$, the specific energy corresponds to $32 \mathrm{~W} \mathrm{~h} \mathrm{~kg}^{-1}$. For comparison, a hybrid full-cell was also evaluated using as positive and negative electrodes CDC-600-3 and $\mathrm{Nb}_{2} \mathrm{O}_{5}-850$ respectively. Due to the lower capacitance of the $\mathrm{CDC}$ fibers compared to the AC (YP80 + 5\% PTFE; $\left.112 \mathrm{~F} \mathrm{~g}^{-1}\right){ }^{60}$ a maximum specific energy of $71 \mathrm{~W} \mathrm{~h} \mathrm{~kg}^{-1}$ was obtained. Above $1 \mathrm{~kW} \mathrm{~kg}^{-1}$, the hybrid electrode system presents a better electrochemical performance maintaining $21 \mathrm{~W} \mathrm{~h} \mathrm{~kg}^{-1}$ at $2.2 \mathrm{~kW} \mathrm{~kg}^{-1}$. Cyclic voltammetry and GCPL of this full-cell are presented in the ESI (see Fig. S11†). 
Table 5 Comparison among different $\mathrm{Nb}_{2} \mathrm{O}_{5}$ containing electrodes characterized as battery-like and redox-hybrid systems. For electrode preparation, most of the samples reported were admixed with carbon as a conductive additive (CA) or drop-casted in the current collector. The capacity values $\left(\mathrm{mAh} \mathrm{g}^{-1}\right.$ ) are normalized by the electrode mass and by the active mass (am), that is, just niobia

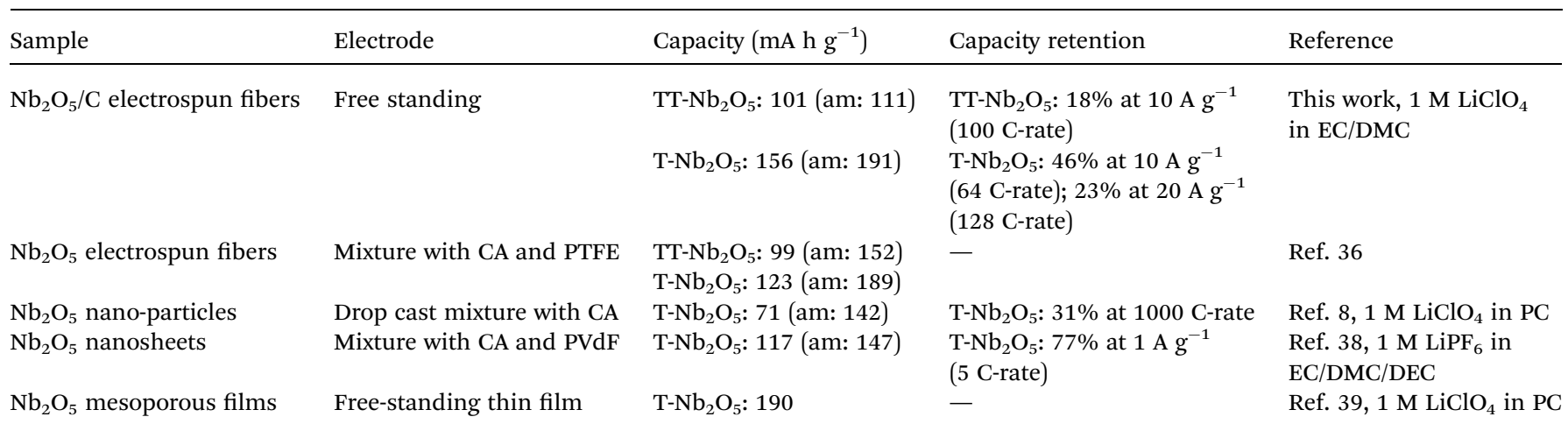

\section{Conclusions}

We demonstrated the suitability of $\mathrm{NbC} / \mathrm{C}$ hybrid nanofibers as a versatile precursor for synthesizing electrode materials for both EDLCs and battery-like systems. Optimized EDLC electrodes were fabricated by chlorine treatment of $\mathrm{NbC} / \mathrm{C}$ nanofibers at $600{ }^{\circ} \mathrm{C}$ in order to obtain a maximum pore volume of $1 \mathrm{~cm}^{3} \mathrm{~g}^{-1}$ and a DFT-SSA of $1369 \mathrm{~m}^{2} \mathrm{~g}^{-1}$. According to the electrochemical performance, due to the highly accessible pore structure, an efficient use of the surface leads to a maximum specific energy of $19.5 \mathrm{~W} \mathrm{~h} \mathrm{~kg}{ }^{-1}$ and $7.6 \mathrm{~W} \mathrm{~h} \mathrm{~kg}^{-1}$ for a maximum specific power of $30 \mathrm{~kW} \mathrm{~kg}^{-1}$ in a full-cell configuration. The high specific power was accomplished due to the continuous path for electron propagation and the high graphitization of the carbon structure.

By the treatment of $\mathrm{NbC} / \mathrm{C}$ nanofibers in oxidative atmospheres, TT- $\mathrm{Nb}_{2} \mathrm{O}_{5}$ and $\mathrm{T}-\mathrm{Nb}_{2} \mathrm{O}_{5} / \mathrm{C}$ hybrid nanofibers were synthesized at $500{ }^{\circ} \mathrm{C}$ and $850{ }^{\circ} \mathrm{C}$, respectively. The synthesis in air $\left(500{ }^{\circ} \mathrm{C}\right)$ does not allow for obtaining a highly crystalline TT- $\mathrm{Nb}_{2} \mathrm{O}_{5}$ phase without oxidizing the carbon phase. By employing $\mathrm{CO}_{2}\left(850^{\circ} \mathrm{C}\right)$, highly crystalline $\mathrm{T}-\mathrm{Nb}_{2} \mathrm{O}_{5}$ engulfed in graphitic carbon was obtained. The higher faradic transfer of charge led to a maximum capacity of $156 \mathrm{~mA} \mathrm{~h} \mathrm{~g}^{-1}$ with respect to the full electrode mass. This value is higher than the values reported in the literature for electrode capacity, since no polymer binder or conductive additive was added to the system. The rapid ion transport characteristic of the $\mathrm{T}-\mathrm{Nb}_{2} \mathrm{O}_{5}$ and the coexistence of a continuous graphitic carbon phase led to an outstanding capacity retention of $50 \%$ at a high rate of $10 \mathrm{~A} \mathrm{~g}^{-1}$ (64 C-rate) in the battery-like system. The electrochemical performance is further highlighted by the superior stability over 5000 discharge cycles (64\% retention). The combination of $\mathrm{Nb}_{2} \mathrm{O}_{5} / \mathrm{C}$ and $\mathrm{AC}$ in an asymmetric full-cell setup led to a specific energy of $86 \mathrm{~W} \mathrm{~h} \mathrm{~kg}^{-1}$, which is among the best values reported for a hybrid full-cell.

Further optimization steps of this promising system will involve enhanced engineering of the synthesis setup. For example, by use of the same furnace for pyrolysis and either chlorine gas treatment or $\mathrm{CO}_{2}$ annealing, the synthesis process can be simplified. Further adaptations of our work may also involve the use of niobium carbide nanopowder instead of electrospun mats. While this may come at the expense of lowered power handling due to the loss of the free-standing and binder-free feature of our electrospun mats, we see possibilities for cost reduction by the use of powder materials.

\section{Acknowledgements}

We acknowledge funding from the German Federal Ministry for Research and Education (BMBF) in support of the nanoEES ${ }^{3 \mathrm{D}}$ project (award number 03EK3013) as part of the strategic funding initiative energy storage framework. This work was supported by the CREATe-Network Project, Horizon 2020 of the European Commission (RISE Project No. 644013). We thank Prof. Eduard Arzt (INM) for his continuing support, and Juhan Lee and Anna Schreiber (all at INM) for useful discussions and technical support.

\section{References}

1 Z. Yang, J. Zhang, M. C. W. Kintner-Meyer, X. Lu, D. Choi, J. P. Lemmon and J. Liu, Chem. Rev., 2011, 111, 3577-3613.

2 P. Simon, Y. Gogotsi and B. Dunn, Science, 2014, 343, 12101211.

3 P. R. Bandaru, H. Yamada, R. Narayanan and M. Hoefer, Mater. Sci. Eng., R, 2015, 96, 1-69.

4 M. Salanne, B. Rotenberg, K. Naoi, K. Kaneko, P. L. Taberna, C. P. Grey, B. Dunn and P. Simon, Nature Energy, 2016, 1, 16070.

5 F. Béguin, V. Presser, A. Balducci and E. Frackowiak, $A d v$. Mater., 2014, 26, 2219-2251.

6 B. Scrosati and J. Garche, J. Power Sources, 2010, 195, 24192430 .

7 M. Schroeder, M. Winter, S. Passerini and A. Balducci, J. Power Sources, 2013, 238, 388-394.

8 V. Augustyn, J. Come, M. A. Lowe, J. W. Kim, P.-L. Taberna, S. H. Tolbert, H. D. Abruña, P. Simon and B. Dunn, Nat. Mater., 2013, 12, 518-522. 
9 J. Lee, B. Kruner, A. Tolosa, S. Sathyamoorthi, D. Kim, S. Choudhury, K.-H. Seo and V. Presser, Energy Environ. Sci., 2016, DOI: 10.1039/c6ee00712k.

10 B. Krüner, J. Lee, N. Jäckel, A. Tolosa and V. Presser, ACS Appl. Mater. Interfaces, 2016, 8, 9104-9115.

11 B. Zhang, F. Kang, J.-M. Tarascon and J.-K. Kim, Prog. Mater. Sci., 2016, 76, 319-380.

12 V. Presser, L. F. Zhang, J. J. Niu, J. McDonough, C. Perez, H. Fong and Y. Gogotsi, Adv. Energy Mater., 2011, 1, 423-430.

13 L. F. Zhang, A. Aboagye, A. Kelkar, C. L. Lai and H. Fong, J. Mater. Sci., 2014, 49, 463-480.

14 N. C. Abeykoon, J. S. Bonso and J. P. Ferraris, RSC Adv., 2015, 5, 19865-19873.

15 M. Rose, E. Kockrick, I. Senkovska and S. Kaskel, Carbon, 2010, 48, 403-407.

16 V. Presser, M. Heon and Y. Gogotsi, Adv. Funct. Mater., 2011, 21, 810-833.

17 J. R. Martin, L. Borchardt, M. Oschatz, G. Mondin and S. Kaskel, Chem. Ing. Tech., 2013, 85, 1742-1748.

18 A. Tolosa, B. Krüner, N. Jäckel, M. Aslan, C. Vakifahmetoglu and V. Presser, J. Power Sources, 2016, 313, 178-188.

19 Y. Korenblit, M. Rose, E. Kockrick, L. Borchardt, A. Kvit, S. Kaskel and G. Yushin, ACS Nano, 2010, 4, 1337-1344.

20 J. Xu, R. Zhang, P. Chen, D. Shen, X. Ye and S. Ge, Carbon, 2013, 64, 444-455.

21 R. Dash, J. Chmiola, G. Yushin, Y. Gogotsi, G. Laudisio, J. Singer, J. Fischer and S. Kucheyev, Carbon, 2006, 44, 2489-2497.

22 C. R. Pérez, S.-H. Yeon, J. Ségalini, V. Presser, P.-L. Taberna, P. Simon and Y. Gogotsi, Adv. Funct. Mater., 2013, 23, 10811089.

23 R. K. Dash, A. Nikitin and Y. Gogotsi, Microporous Mesoporous Mater., 2004, 72, 203-208.

24 M. Xianwen, T. A. Hatton and C. R. Gregory, Curr. Org. Chem., 2013, 17, 1390-1401.

25 S. Cavaliere, S. Subianto, I. Savych, D. J. Jones and J. Roziere, Energy Environ. Sci., 2011, 4, 4761-4785.

26 M. Zeiger, D. Weingarth and V. Presser, ChemElectroChem, 2015, 2, 1117-1127.

27 M. Zhi, A. Manivannan, F. Meng and N. Wu, J. Power Sources, 2012, 208, 345-353.

28 J.-G. Wang, Y. Yang, Z.-H. Huang and F. Kang, Electrochim. Acta, 2011, 56, 9240-9247.

29 Y.-W. Ju, G.-R. Choi, H.-R. Jung, C. Kim, K.-S. Yang and W.-J. Lee, J. Electrochem. Soc., 2007, 154, A192-A197.

30 Y. Wu, R. Balakrishna, M. V. Reddy, A. S. Nair, B. V. R. Chowdari and S. Ramakrishna, J. Alloys Compd., 2012, 517, 69-74.

31 J. Come, V. Augustyn, J. W. Kim, P. Rozier, P.-L. Taberna, P. Gogotsi, J. W. Long, B. Dunn and P. Simon, J. Electrochem. Soc., 2014, 161, A718-A725.

32 J. W. Kim, V. Augustyn and B. Dunn, Adv. Energy Mater., 2012, 2, 141-148.

33 R. A. Rani, A. S. Zoolfakar, A. P. O'Mullane, M. W. Austin and K. Kalantar-Zadeh, J. Mater. Chem. A, 2014, 2, 15683-15703.

34 B. Reichman and A. J. Bard, J. Electrochem. Soc., 1980, 127, 241-242.
35 R. Kodama, Y. Terada, I. Nakai, S. Komaba and N. Kumagai, J. Electrochem. Soc., 2006, 153, A583-A588.

36 A. L. Viet, M. V. Reddy, R. Jose, B. V. R. Chowdari and S. Ramakrishna, J. Phys. Chem. C, 2010, 114, 664-671.

37 C. Zhang, R. Maloney, M. R. Lukatskaya, M. Beidaghi, B. Dyatkin, E. Perre, D. Long, W. Qiao, B. Dunn and Y. Gogotsi, J. Power Sources, 2015, 274, 121-129.

38 M. Liu, C. Yan and Y. Zhang, Sci. Rep., 2015, 5, 8326.

39 K. Brezesinski, J. Wang, J. Haetge, C. Reitz, S. O. Steinmueller, S. H. Tolbert, B. M. Smarsly, B. Dunn and T. Brezesinski, J. Am. Chem. Soc., 2010, 132, 6982-6990.

40 J. S. Atchison, M. Zeiger, A. Tolosa, L. M. Funke, N. Jackel and V. Presser, RSC Adv., 2015, 5, 35683-35692.

41 P. Scherrer, Nachr. Ges. Wiss. Goettingen, Math.-Phys. Kl., 1918, 98-100.

42 S. Brunauer, P. H. Emmett and E. Teller, J. Am. Chem. Soc., 1938, 60, 309-319.

43 G. Y. Gor, M. Thommes, K. A. Cychosz and A. V. Neimark, Carbon, 2012, 50, 1583-1590.

44 P. W. Ruch, D. Cericola, M. Hahn, R. Kötz and A. Wokaun, J. Electroanal. Chem., 2009, 636, 128-131.

45 R. Kötz and M. Carlen, Electrochim. Acta, 2000, 45, 24832498.

46 A. C. Ferrari, Solid State Commun., 2007, 143, 47-57.

47 A. C. Ferrari and D. M. Basko, Nat. Nanotechnol., 2013, 8, 235-246.

48 K. Faber, F. Badaczewski, M. Oschatz, G. Mondin, W. Nickel, S. Kaskel and B. M. Smarsly, J. Phys. Chem. C, 2014, 118, 15705-15715.

49 M. Thommes, K. Kaneko, A. V. Neimark, J. P. Olivier, F. Rodriguez-Reinoso, J. Rouquerol and K. S. W. Sing, Physisorption of Gases, with Special Reference to the Evaluation of Surface Area and Pore Size Distribution (IUPAC Technical Report), 2015.

50 D. Weingarth, M. Zeiger, N. Jäckel, M. Aslan, G. Feng and V. Presser, Adv. Energy Mater., 2014, 4, 1400316.

51 J. Chmiola, C. Largeot, P.-L. Taberna, P. Simon and Y. Gogotsi, Angew. Chem., Int. Ed., 2008, 47, 3392-3395.

52 J. Segalini, E. Iwama, P.-L. Taberna, Y. Gogotsi and P. Simon, Electrochem. Commun., 2012, 15, 63-65.

53 R. Kötz, M. Hahn and R. Gallay, J. Power Sources, 2006, 154, 550-555.

54 L. Shi, Y. Gu, L. Chen, Z. Yang, J. Ma and Y. Qian, Solid State Ionics, 2005, 176, 841-843.

55 M. V. Reddy, R. Jose, A. Le Viet, K. I. Ozoemena, B. V. R. Chowdari and S. Ramakrishna, Electrochim. Acta, 2014, 128, 198-202.

56 T. Ikeya and M. Senna, J. Non-Cryst. Solids, 1988, 105, 243250.

57 V. L. S. Teixeira da Silva, M. Schmal and S. T. Oyama, J. Solid State Chem., 1996, 123, 168-182.

58 M. S. Dresselhaus, G. Dresselhaus, R. Saito and A. Jorio, Phys. Rep., 2005, 409, 47-99.

59 S. Fleischmann, N. Jäckel, M. Zeiger, B. Krüner, I. Grobelsek, P. Formanek, S. Choudhury, D. Weingarth and V. Presser, Chem. Mater., 2016, 28, 2802-2813. 
60 N. Jäckel, D. Weingarth, A. Schreiber, B. Krüner, M. Zeiger, A. Tolosa, M. Aslan and V. Presser, Electrochim. Acta, 2016, 191, 284-298.

61 A. Meier, M. Weinberger, K. Pinkert, M. Oschatz, S. Paasch, L. Giebeler, H. Althues, E. Brunner, J. Eckert and S. Kaskel, Microporous Mesoporous Mater., 2014, 188, 140-148.

62 N. Jäckel, D. Weingarth, A. Schreiber, B. Krüner, M. Zeiger, A. Tolosa, M. Aslan and V. Presser, Electrochim. Acta, 2016, 191, 284-298. 